Journal of Management Studies 55:6 September 2018

doi: $10.1111 /$ joms.12331

\title{
Corporate Governance in China: A Meta-Analysis
}

\section{Ganan C. Mutlu ${ }^{a}$, Marc Van Essen ${ }^{\text {b,c }}$, Mike W. Peng ${ }^{d}$, Sabrina F. Saleh ${ }^{\mathbf{b}}$ and Patricio Duran ${ }^{\mathrm{e}}$}

${ }^{a}$ Coles College of Business, Kennesaw State University; ${ }^{b}$ Darla Moore School of Business, University of South Carolina; 'EM LYON Business School; 'findal School of Management, University of Texas at Dallas; ${ }^{e}$ Universidad Adolfo Ibáñez

ABSTRACT How has the impact of 'good corporate governance' principles on firm performance changed over time in China? Amassing a database of 84 studies, 684 effect sizes, and 547,622 firm observations, we explore this important question by conducting a metaanalysis on the corporate governance literature on China. The weight of evidence demonstrates that two major 'good corporate governance' principles advocating board independence and managerial incentives are indeed associated with better firm performance. However, we cannot find strong support for the criticisms against CEO duality. In addition, we go beyond a static perspective (such as certain governance mechanisms are effective or ineffective) by investigating the temporal hypotheses. We reveal that over time, with the improvement in the quality of market institutions and development of financial markets, the monitoring mechanisms of the board and state ownership become more strongly related to firm performance, whereas the incentive mechanisms lose their significance. Overall, our findings advance a dynamic institution-based view by substantiating the case that institutional transitions matter for the relationship between governance mechanisms and firm performance in the second largest economy in the world.

Keywords: board independence, GEO duality, China, corporate governance, financial market development, institutional change, institution-based view, managerial incentives, meta-analysis, state ownership

\section{INTRODUGTION}

Since market reforms started in the 1980s, China has not only restructured state-owned enterprises (SOEs), but also adopted a series of corporate governance mechanisms centred on monitoring and alignment principles from Western economies in an effort to enhance firm performance. Outside of China, there is a tradition of research arguing

Address for reprints: Canan C. Mutlu, Coles College of Business, Kennesaw State University, Kennesaw, GA 30144, USA (cmutlu@kennesaw.edu). 
that board composition, leadership structure, and incentive mechanisms can influence organizational outcomes (Dalton et al., 1998, 2007). Given the significant institutional differences between China and developed economies, an important debate continues to rage over the impact of standard governance mechanisms on firm performance in China (Li et al., 2016; Peng, 2004; Tsui, 2007). Standard monitoring and alignment mechanisms are hinged upon the assumptions of self-orientation (Bruce et al., 2005; Davis, 2005) and market maturity (Young et al., 2008), which may not be a natural fit for economies characterized by relationship-based regimes and underdeveloped market institutions (Sundaramurthy and Lewis, 2003). Scholars, therefore, recommend invoking an institution-based view by incorporating institutional factors to better understand the contextual nature of corporate governance problems (Haxhi and Aguilera, 2017; Meyer and Peng, 2016; Peng and Jiang, 2010).

The institution-based view focuses not only on how institutions affect firm behaviour, but also on how changes in institutions over time shape firm strategic choices and performance (Meyer and Peng, 2016; North, 1990; Peng, 2003). This temporal dimension warrants a temporal lens to explore the impact of changing institutions on corporate governance mechanisms across firms, resulting in a dynamic institution-based view (Banalieva et al., 2015; Kim et al., 2010). China is a prime context in which a dynamic institution-based view of corporate governance can be advanced. First, it represents an 'important counterexample to the findings in the law, institutions, finance, and growth literature' (Allen et al., 2005, p. 57) by accomplishing strong economic growth despite having relatively underdeveloped formal institutions. Although agency theory underpins much of the corporate governance literature (Shleifer and Vishny, 1997), whether (and how) standard corporate governance mechanisms that are largely based on agency theory prescriptions play a role in China remains to be clarified. Second, due to the gradual improvement of market institutions, China is considered as a 'hybrid' (1) between central planning and market competition (Allen et al., 2005) and (2) between relationship-based and rule-based regimes (Luen et al., 2013). Gradual market reforms play a crucial role as they alter the institutional framework to improve the functioning of product, capital, and labour markets. In turn, improvements in these external governance mechanisms help the functioning of internal governance mechanisms by emphasizing arm's-length monitoring, which may reduce agency costs and ultimately help firm performance (Guervo-Cazurra and Dau, 2009; Peng, 2003, 2004). This hybrid form of institutional change and gradual corporate governance reforms in China lead to our question: How has the impact of (1) board independence, (2) board leader-ship structure, (3) managerial incentives, and (4) state ownership on firm performance changed over time?

We focus on these widely used and important internal governance elements in Chinese firms for scholarly and practical reasons. Scholarly, board independence and managerial incentives are widely viewed as two key elements of internal corporate governance mechanisms to deter managerial self-interest and encourage shareholder orientation (Dalton et al., 1998, Tosi et al., 2000). State ownership has also intrigued scholarly attention, as Chinese SOEs have been pivotal in implementing corporate governance reforms (Peng et al., 2016; Ralston et al., 2006). From a practical standpoint, these mechanisms are the key initiatives of Chinese corporate governance reforms to 
establish modern enterprise systems (Jiang and Kim, 2015; Peng, 2004). The most notable reforms in China have included appointing outside directors, separating the positions of board chair and chief executive officer (CEO), and providing executive compensation packages that include contingent forms of pay - underpinned by what are generally viewed as 'good' or standard corporate governance principles (Chen et al., 2011b). These reforms and their impact on firm outcomes has therefore provoked increasing scholarly attention in the context of China, making them the most widely studied forms of internal corporate governance (Li et al., 2016; Tsui, 2007).

However, there are two problems in the scholarly work on corporate governance in China. First, evidence from numerous studies using data from China remains mixed (Buck et al., 2008; Peng, 2004). Such mixed results call for efforts to weigh different and conflicting evidence. Second, although the corporate governance literature has started to embrace the 'context matters' perspective, it is relatively silent about the temporal dimension that requires a closer analysis of the role of space and time together (Ancona et al., 2001; Kim et al., 2010; Shi et al., 2012). Therefore, we address our question in two steps. In our first step, we explore the overall strength of the relationship between internal corporate governance mechanisms and firm performance by using advanced meta-analysis techniques. Second, we go beyond a static approach and explore how these relationships change over time as Chinese market institutions improve. Employing a temporal lens is crucial given the gradual reforms in China that, unlike rapid transitions in Central and Eastern Europe, provide a dynamic yet relatively predictable platform that allows firms time to adapt (Newman, 2000). Therefore, we incorporate an objective view of time such that we rely upon it as a proxy for gradual market reforms (Mosakowski and Earley, 2000). Ignoring the effect of time and the related changes in the complementary governance mechanisms may lead to an incomplete understanding of the relationship between internal governance principles and firm outcomes (Lawrence et al., 2001). Using time as a moderator, therefore, enables us to have a finer-grained understanding of the role of time, which provides new opportunities for explanation and prediction of institutional dynamism and firm outcomes (Ancona et al., 2001; Shi et al., 2012).

This study endeavours to make two contributions. First, we provide a comprehensive account of the impact of corporate governance mechanisms in China. Despite relatively efficient market institutions in developed economies, meta-analyses find little evidence of a significant positive effect of board monitoring (Dalton et al., 1998; Wagner et al., 1998) and alignment mechanisms (Tosi et al., 2000; Van Essen et al., 2012a) on firm performance. Therefore, it is not clear if such standard governance mechanisms would have an impact in China (Chen et al., 2011b; Peng, 2004). Through our meta-analysis, we contribute to this debate in the Chinese context with quantitative evidence. The literature on corporate governance in China has featured a few narrative reviews (Clarke, 2003; Guo et al., 2013; Jiang and Kim, 2015; Yang et al., 2011). By complementing the qualitative review literature, our meta-analytic investigation provides a quantitative assessment of the vast amount of empirical studies (Eden, 2002).

Second, we extend the corporate governance literature by exploring the temporal effect of internal corporate governance mechanisms on firm performance, rather than reporting a static perspective or a snapshot. We benefit from the growing amount of 
research conducted over the years on corporate governance in China to underpin the role of time as a proxy for institutional dynamism. The incorporation of a temporal perspective is critical to assess how the co-evolution of external and internal corporate governance reforms influences firms that compete in this dynamic reality (Banalieva et al., 2015; Mosakowski and Earley, 2000; Shi et al., 2012). Thus, we leverage a dynamic institution-based view to explore whether the internal governance mechanisms become more effective in China as market institutions come of age (Banalieva et al., 2015; Peng, 2003). While our study covers a particular institutional context, our findings complement other meta-analytic reviews by integrating the role of time and related market reforms on the inner workings of 'good' corporate governance mechanisms.

Amassing a database of 84 studies, 684 effect sizes, and 547,622 firm observations, our findings indicate that with the improvement in market institutions and the development of financial markets, the monitoring mechanisms of the board become more important whereas the incentive mechanisms lose their significance. We also report that, despite an overall negative relationship, state ownership tends to be linked more strongly to firm performance over time, indicating that SOE restructuring along with the improvement in the quality of market institutions and development of financial markets help increase SOE performance.

\section{EVOLUTION OF GORPORATE GOVERNANGE MEGHANISMS IN CHINA}

In the 1980s, the development of corporate governance in China started with the decentralization of SOEs and the empowerment of managers (Groves et al., 1994; Huang et al., 2017). Unlike the rapid reforms in Central and Eastern Europe, China has adopted a gradual strategy aimed at facilitating a market-based economy that gradually generates more efficient product, capital, and labour markets. During institutional transitions, the old system has co-existed and co-evolved with the requirements of the new market-oriented system that helped reduce uncertainty and upheaval (Newman, 2000; Peng et al., 2015). The launch of the Shanghai and Shenzhen Stock Exchanges in 1990 and 1991, respectively, represented one of the most important steps toward market reforms that initiated the rise of modern enterprise systems. Publicly listed firms were now exposed to higher levels of external scrutiny, leading to further reforms focused on firms' internal governance mechanisms (Clarke, 2003). A major goal of these institutional reforms was to supplement direct state control with economic incentives for managers (Groves et al., 1994). Summarized in Table I, corporate governance in China has experienced continuous reforms over the decades, which can be categorized into three stages (Jiang and Kim, 2015).

During this transformation, the more notable reforms concerning internal governance mechanisms included mandating board independence to increase the monitoring power of corporate boards and formulating contingent forms of executive pay to align managerial interests with those of shareholders. However, the transfer of such a governance model may pose applicability problems in China for two reasons. First, standard internal governance structures assume effective external governance mechanisms - namely, strong shareholder protection and competitive product and labour markets (Young 
Table I. Three stages of institutional transitions of corporate governance in China

\begin{tabular}{|c|c|c|}
\hline & Key events & Implications \\
\hline $\begin{array}{l}\text { Stage 1 } \\
1980-1989\end{array}$ & $\begin{array}{l}\text { - Enterprise reform; privatization of SOEs } \\
\text { - Introduction of SOE law to clarify prop- } \\
\text { erty rights and to implement incentive } \\
\text { contracts (1988) }\end{array}$ & $\begin{array}{l}\text { - Ownership and control problems } \\
\text { still constrained the effectiveness } \\
\text { of the incentive contracts between } \\
\text { the government and the } \\
\text { management. } \\
\text { - The need for a basic corporate } \\
\text { governance framework emerged. }\end{array}$ \\
\hline $\begin{array}{l}\text { Stage } 2 \\
1990-1999\end{array}$ & $\begin{array}{l}\text { - Launch of Shanghai and Shenzhen Stock } \\
\text { Exchanges } \\
\text { - Launch of the Company Law (1993) and } \\
\text { the Security Law (1999) }\end{array}$ & $\begin{array}{l}\text { - Structural changes such as the for- } \\
\text { mation of board of directors, the } \\
\text { supervisory board, and mandatory } \\
\text { annual shareholder meetings were } \\
\text { introduced. } \\
\text { - The establishment of a modern } \\
\text { enterprise system sped up. }\end{array}$ \\
\hline $\begin{array}{l}\text { Stage } 3 \\
\text { 2000-present }\end{array}$ & $\begin{array}{l}\text { - Revision of corporate laws (e.g. company } \\
\text { law, accounting law, securities law) } \\
\text { - Accession to the World Trade Organiza- } \\
\text { tion (2001) } \\
\text { - Introduction of the Code of Corporate } \\
\text { Governance of Listed Companies (2002) } \\
\text { - The } 2005 \text { non-tradable share reform }\end{array}$ & $\begin{array}{l}\text { - Improvements in the quality of dis- } \\
\text { closures and transparency. } \\
\text { - Convergence to international } \\
\text { standards (e.g., rules about having } \\
\text { independent directors on board). }\end{array}$ \\
\hline
\end{tabular}

Sources: Liang et al. (2016), Tenev and Zhang (2002), Yang et al. (2011).

et al., 2008). In China, since these conditions are not fully met, the execution of standard governance structures may prove to be problematic (Allen et al., 2005). Second, the key assumptions of standard corporate governance mechanisms regarding self-interested agents and goal conflicts may not hold in contexts characterized by relationship-based governance regimes (Bruce et al., 2005; Chua et al., 2009; Gomez-Mejia et al., 2005; Luen et al., 2013). Multiple studies highlight the critical role of guanxi (connections) in helping firms secure critical resources and overcome institutional disadvantages (Park and Luo, 2001). Thus, the effectiveness of policy prescriptions embedded in codes of 'good' corporate governance remains questionable (Chen et al., 2011b; Filatotchev and Allcock, 2010).

The literature on China is therefore mixed in the overall effects of standard corporate governance mechanisms on firm performance. Some studies report that 'good' governance mechanisms indeed make a difference in firm performance (Bai et al., 2004; Buck et al., 2008), and other studies fail to do so (Peng, 2004; Tian and Lau, 2001). The reason that the evidence is inconclusive may be that these studies overlook the impact of temporal changes in the institutional environment, which complicates the interdependencies among internal and external corporate governance mechanisms. Such a static view ignores the dynamic reality in which firms compete. This calls for a need to incorporate time to understand the nature and evolution of corporate governance matters (Banalieva et al., 2015; Mosakowski and Earley, 2000; Shi et al., 2012). Therefore, it is 
crucial to understand whether (and how) market reforms and financial development over time raise the significance of internal governance mechanisms - a perspective we further develop next.

\section{MONITORING MEGHANISMS}

\section{Board Independence}

As part of broader governance reforms, China as of 2001 required publicly-listed firms to appoint outside directors on corporate boards and mandated at least one-third of the board to be independent (Conyon and He, 2011). Outside directors are expected to help firm performance for two reasons. First, outside directors are believed to bring more diversity and greater objectivity to decision-making, and consequently are better representatives of shareholders' interests. Second, outside directors are likely to be motivated to monitor the CEO, because they may have higher sensitivity for personal reputation and credibility in the labour market for directors (Ma and Khanna, 2016). However, one side of the debate suggests that China's relationship-based culture makes outside directors ineffective (Liang et al., 2016). For example, many Chinese CEOs refuse to cooperate with some outside directors, with whom the CEOs may have no prior personal relationship (Tian and Lau, 2001).

Accordingly, the literature on China is at best mixed on the overall effects of outside directors (Peng, 2004). Despite the mixed findings, we argue that outside directors are likely to be concerned with shareholder interests, and that this effect may be particularly heightened in China given the importance of personal relations and credibility in the society. For example, Chen et al. (2006) report that outside directors help minimize corporate frauds to avoid association with unethical decisions. Moreover, unlike many developed economies, China requires the disclosure of director voting record in securities filings, adding an additional level of sensitivity to outside directors' concern for better monitoring (Jiang et al., 2016). Hence, the importance of personal relations and credibility in the society coupled with regulatory disclosure requirements about director voting behaviour may increase outside directors' career and reputation concerns, which promote alignment with firm shareholders.

However, institutions in China are in a state of flux that requires a better understanding of the role of time and the relationship between initiatives such as board independence and firm performance (Peng, 2004). This is critical because market reforms support the workings of internal governance mechanisms and both have been subject to continuous change over the last decades in China. Based on a temporal perspective, such new dynamics in the internal monitoring mechanisms have been supported with external regulatory and market reforms that further elevate the role of corporate boards and director diligence. These temporal changes over time have not only changed board composition, but also sensitized board directors for higher quality decisions. This dynamic in the formal institutions is parallel to the decline of relationship-based structures and thus the value of personal connections as market institutions advance (Peng, 2003). For example, recent corporate governance amendments have expanded the role of outside directors through election mechanisms, terms of reference, and responsibility 
investigation (OECD, 2011). In addition to the regulatory structures, a more efficient labour market for directors enhances outside directors' sensitivity for personal reputation and credibility. Outside directors' sensitive monitoring is increasingly rewarded in the directors' labour market via greater career opportunities and avoidance of regulatory sanctions (Jiang et al., 2016). Furthermore, to meet transparency requirements, Chinese listed firms have begun reporting key board activities such as outside directors' dissent during board meetings (Ma and Khanna, 2016). The design of such reforms created additional levels of sensitivity to outside directors' concern for better monitoring and oversight (Sauerwald et al., 2018). Therefore:

Hypothesis 1a: Board independence is positively related to firm performance.

Hypothesis $1 \mathrm{~b}$ : The relationship between board independence and firm performance becomes more positive over time.

\section{CEO Duality}

CEO duality - the situation when the CEO also holds the position of chairman of the board - has been one of the most controversial constructs in corporate governance research. On the one hand, Chen et al. (2006) report that CEO duality reduces the checks and balances in top management. On the other hand, GEO duality may lead to the unity of command, which enables more efficient decision-making (Peng et al., 2007, 2010). Like the inconclusive evidence on the effects of GEO duality from developed economies (Dalton and Dalton, 2011; Krause et al., 2013), the findings based on Chinese firms are also largely inconclusive (Chen et al., 2011b; Peng et al., 2007, 2010).

CEO duality in China is likely to be associated with political connections that lead to CEOs acting as the stewards of the state or of their political connections rather than working for the best interest of shareholders (Tian and Lau, 2001). The absence of separate decision-making and control mechanisms, therefore, may result in negative outcomes. For example, Firth et al. (2014) show that CEO duality leads to CEO entrenchment despite declining firm performance. Similarly, Li and Tang (2010) highlight excessive managerial discretion and risk taking as a consequence of CEO duality. As a result, Bai et al. (2004) emphasize the negative impact of CEO duality on firm market valuation. Overall, there is no shortage of criticisms against CEO duality.

Although CEO duality represents strong managerial power and high reliance on personal and political connections in China, a temporal perspective suggests that institutional transitions may diminish the potential value of relationship-based strategies over time (Khanna and Palepu, 2000; Peng, 2003). Specifically, the gradual decline of the state's influence and the increasing influence of capital markets have increasingly led managers to become accountable to external market forces rather than to the state or their political connections (Firth et al., 2007a, 2007b, 2007c). For example, Fan et al. (2007) show that Chinese firms with politically connected CEOs underperform those without politically connected CEOs. In other words, the performance effects of personal and political relations may decline as market institutions advance (Peng, 2003). This 
shift illustrates some gradual transformation from a relationship-based to a rule-based governance regime that may reduce the effectiveness of CEO duality.

In sum, criticisms against $\mathrm{CEO}$ duality suggest that $\mathrm{CEO}$ duality may reduce the effectiveness of board monitoring. Based on a dynamic institution-based view (Banalieva et al., 2015; Peng, 2003), as China transforms toward a rule-based society with better market institutions, the adverse effect of CEO duality on monitoring may be heightened as inadequate oversight by the board contributes to the misalignment of $\mathrm{CEO}$ and shareholder interests. Therefore:

Hypothesis 2a: CEO duality is negatively related to firm performance.

Hypothesis 2b: The relationship between $\mathrm{CEO}$ duality and firm performance becomes more negative over time.

\section{ALIGNMENT MEGHANISMS}

Managerial incentives are instruments to minimize moral hazard problems that result from the self-interested actions of managers. Since institutions matter in the relationship between managerial pay and firm performance (Van Essen et al., 2012a), the implications of this mechanism have been a source of debate in the corporate governance literature on China (Buck et al., 2008; Markoczy et al., 2013; Peng et al., 2015). Some studies argue that $\mathrm{CEO}$ pay may not be an effective alignment mechanism because the politically oriented institutional environment and relationship-based governance regime limit the effectiveness of remuneration systems that prevail in developed economies (Liang et al., 2016). Therefore, managerial pay is not necessarily linked to CEO performance, but to CEOs' political ties and status.

In contrast, another line of work emphasizes the effectiveness of the new incentive mechanisms in China (Conyon and He, 2011). Until the 1980s, all executive appointments and pay structures were regulated based on civil service seniority (Adithipyangkul et al., 2011; Buck et al., 2008). From the early 1980s onwards, a contract-based responsibility system was introduced that promoted the separation of the government from firms and provided managers with greater autonomy and incentives (Groves et al., 1994). As a result, some studies report a positive relationship between executive pay and firm performance (Chen et al., 2011a; Conyon and He, 2011; Firth et al., 2007a, 2007b, 2007c; Kato and Long, 2006). Groves et al. (1994) demonstrate how reforms helped the effectiveness of the incentive mechanisms and heightened the overall productivity of Chinese firms. Buck et al. (2008) further document a two-way relationship between executive pay and firm performance. The rationale is that executives are motivated to attain certain targets such as sales and market shares that would lead to increased share prices and eventually higher remuneration.

From a temporal perspective, the relationship between managerial incentives and firm performance may be even stronger, considering the market reforms that facilitate more efficient capital and labour markets. In particular, China's gradual transitions to market competition have introduced executive compensation mechanisms that are 
benchmarked on the compensation principles (if not the scale) of the Anglo-American model (Firth et al., 2006; Markoczy et al., 2013). In addition to contingent pay systems, related regulatory changes have supported this institutional shift. For example, by 2005, it became mandatory for publicly-listed firms to report the total compensation of each executive and board member individually (Conyon and He, 2011). Together these reforms 'introduced incentive mechanisms to induce managers to change from passive command-driven behaviour to having a corporate mentality' (Bai and $\mathrm{Xu}, 2005$, p. 525). The new incentive system thus aims to highlight accountability towards shareholder and firm interests, rather than personal connections.

Another factor that may have strengthened the relationship between managerial incentives and firm performance over time is the development of capital and labour markets. Efficient capital and labour markets act as information mechanisms that control the potentially self-serving behaviour of managers. As capital markets and related financial reforms become more influential in China, empirical studies indicate a stronger effect of alignment mechanisms on firm outcomes over time (Chen et al., 2011 a; Conyon and He, 2011; Firth et al., 2007a, 2007b, 2007c; Kato and Long, 2006). Indeed, as a reflection of the new reforms, the ratio of corporate boards with a compensation committee has increased from 8 per cent in 2000 to 62 per cent in 2006, indicating the increasing emphasis placed on using managerial incentives to control managerial behaviour (Markoczy et al., 2013).

In summary, because of the decentralization of SOEs and the adoption of new incentive mechanisms, managerial incentives act as instruments to motivate managers towards increasing firm performance and pursuing shareholder interests in China. From a temporal view, such a relationship may become more pronounced as reforms deepen. Therefore:

Hypothesis 3a: Managerial incentives are positively related to firm performance.

Hypothesis 3b: The relationship between managerial incentives and firm performance becomes more positive over time.

\section{STATE OWNERSHIP}

In China, pre-reform SOEs were the prototype organizations in a planned economy, with a focus on internal matters such as meeting production levels and with little concern for external factors (Peng and Heath, 1996; Sheng and Zhao, 2012). Traditionally, SOEs are not necessarily known for their drive for profit maximization (Ghosh and Whalley, 2008). Thus, SOEs are often found to be less efficient compared to their private counterparts (Dewenter and Malatesta, 2001; Megginson and Netter, 2001).

However, the outlook of the SOEs has gradually changed over time. This requires a temporal lens to explore SOE transformation and its impact on economic outcomes (Bruton et al., 2015; Peng et al., 2016). Because of the gradual market reforms, many Chinese SOEs have been transformed into significant economic players. They have been particularly pivotal in implementing corporate governance reforms, which have two characteristics. First, the adoption of the modern enterprise systems in the 1990s 
facilitated the restructuring of SOEs based on Western management philosophy (Ralston et al., 2006). These reforms exposed SOEs to the scrutiny of both internal and external governance mechanisms such as the board of directors and public investors (Tenev and Zhang, 2002). During institutional transitions, SOEs have gained greater autonomy regarding strategic decisions and profit allocation (Peng et al., 2016). To respond to the increasing market pressures, the State-Owned Assets Supervision and Administration Commission (SASAC) started to intervene less by giving more authority to SOE boards and managers. Indeed, SOE boards now have the authority to hire or fire executives depending on performance (Jiang and Kim, 2015).

Second, because of the market reforms and the increasing integration of the Chinese economy with the rest of the world, Chinese SOEs face intense product market competition from both private and foreign-owned companies (Mutlu et al., 2015). The competitive pressure has led some Chinese SOEs to become competitive players not only locally, but also increasingly globally (Peng et al., 2015, 2016). This is especially evident in industries such as telecommunications, banking, pharmaceuticals, electronics, and petrochemical - in which SOEs are prominently active (Ralston et al., 2006).

In sum, state ownership has traditionally been a drag on firm productivity and performance in China. However, considering the temporal role of market reforms that primarily focuses on developing a market orientation for SOEs in China (Peng et al., 2016), we suggest that many SOEs have evolved into strategic players and adapted to the new realm of corporate governance. Therefore:

Hypothesis 4a: State ownership is negatively related to firm performance.

Hypotheses 4b: The relationship between state ownership and firm performance becomes more positive over time.

\section{METHODS}

\section{Sample and Coding}

We employed five search strategies to identify relevant studies in China. ${ }^{[1]}$ First, we consulted prior qualitative review articles (Claessens and Fan, 2002; Clarke, 2003; Globerman et al., 2011; Kang et al., 2008; Liang et al., 2016; Yang et al., 2011; Young et al., 2008). Second, we explored five electronic databases: (1) ABI/INFORM Global, (2) EconLit, (3) Google Scholar, (4) JSTOR, and (5) SSRN, using the following search terms: 'board independence', 'independent directors', 'board size', 'executive directors', 'non-executive directors', 'CEO duality', 'pay', 'compensation', 'inside ownership', 'CEO ownership', 'top executive ownership', 'board ownership', 'state ownership', and 'SOE'. Third, we manually searched 25 leading economics, finance, and management journals. Fourth, we searched all references of the retrieved studies, as well as all articles citing them using Google Scholar and ISI Web of Knowledge. Fifth, we called for relevant published or unpublished studies via major academic communities (such as conferences and list-servs). These efforts yielded a final sample of 84 primary studies marked with an asterisk $\left(^{*}\right)$ in the references. Table II provides the operationalization of the 
Table II. Definitions and measures

\begin{tabular}{|c|c|c|c|}
\hline \multirow[b]{2}{*}{ Predictor } & \multirow[b]{2}{*}{ Definition and measures } & $\underline{r_{x y, z}}$ & $-r$ \\
\hline & & $\begin{array}{l}\text { Number of } \\
\text { samples }\end{array}$ & $\begin{array}{l}\text { Number of } \\
\text { samples }\end{array}$ \\
\hline \multirow[t]{13}{*}{ Board independence } & Definition: The extent to which the board of directors & & \\
\hline & operates independently from corporate insiders. Com- & & \\
\hline & monly measured as the proportion of outside board mem- & & \\
\hline & $\begin{array}{l}\text { bers to total number of board members. For Cihinas two- } \\
\text { tier board system, information is sometimes available for }\end{array}$ & & \\
\hline & independence of supervisory board and management & & \\
\hline & board (Cho and Rui, 2009; Peng, 2004). & & \\
\hline & Measures: & & \\
\hline & Ratio of independent directors to total directors & 74 & 65 \\
\hline & $\begin{array}{l}\text { Ratio of independent directors is above the median value } \\
\text { of yearly observations (dummy) }\end{array}$ & - & 1 \\
\hline & $\begin{array}{l}\text { Ratio of independent directors is above the cross-sectional } \\
\text { median (dummy) }\end{array}$ & 2 & 1 \\
\hline & Ratio of independent supervisory members & - & 4 \\
\hline & Number of independent directors on the board & 2 & 1 \\
\hline & $\begin{array}{l}\text { If independent directors occupy at least one-third of the } \\
\text { board seats (dummy) }\end{array}$ & 1 & 1 \\
\hline \multirow[t]{2}{*}{ CEO duality } & $\begin{array}{l}\text { Definition: Situation where the positions of board chair- } \\
\text { man and CEO are held by one individual. It is a dummy } \\
\text { variable coded } 1 \text { for CEO duality and } 0 \text { for non-duality } \\
\text { (Lin and Liu, } 2009 \text {; Peng et al., 2010). } \\
\text { Measures: }\end{array}$ & & \\
\hline & CEO is also chairman of the board (dummy) & 56 & 49 \\
\hline \multirow[t]{4}{*}{ CEO pay } & $\begin{array}{l}\text { Definition: Total annual cash compensation of the exec- } \\
\text { utives. In the Chinese context, CEO total pay is measured } \\
\text { as the sum of total cash pay (salary and bonus) in a year } \\
\text { earned by the top executives (Buck et al., 2008; Peng } \\
\text { et al., 2015). } \\
\text { Measures: }\end{array}$ & & \\
\hline & Average cash salaries and bonus & 3 & 8 \\
\hline & Average top executives compensation & 4 & 7 \\
\hline & $\begin{array}{l}\text { Managers' compensation relative to earnings before inter- } \\
\text { est and taxes }\end{array}$ & - & 2 \\
\hline \multirow[t]{5}{*}{ Managerial ownership } & $\begin{array}{l}\text { Definition: The extent to which a firm's outstanding } \\
\text { stock is owned by CEO, top executives, and board mem- } \\
\text { bers. We also incorporate dummy variables of manage- } \\
\text { ment ownership (Liu and Lu, 2007; Peng, 2004). } \\
\text { Measures: }\end{array}$ & & \\
\hline & CEOs hold ownership (dummy) & 2 & 1 \\
\hline & TMTs hold ownership (dummy) & 3 & - \\
\hline & $\begin{array}{l}\text { The percentage of CEO shareholdings to total shares } \\
\text { outstanding }\end{array}$ & 6 & 6 \\
\hline & $\begin{array}{l}\text { The percentage of director shareholdings to total shares } \\
\text { outstanding }\end{array}$ & 6 & 24 \\
\hline
\end{tabular}




\begin{tabular}{|c|c|c|c|}
\hline \multirow[b]{2}{*}{ Predictor } & \multirow[b]{2}{*}{ Definition and measures } & \multirow{2}{*}{$\begin{array}{l}r_{x y, z} \\
\text { Number of } \\
\text { samples }\end{array}$} & \multirow{2}{*}{$\begin{array}{l}\text { Number of } \\
\text { samples }\end{array}$} \\
\hline & & & \\
\hline & $\begin{array}{l}\text { The percentage of management shareholdings to total } \\
\text { shares outstanding }\end{array}$ & 49 & 22 \\
\hline \multirow[t]{3}{*}{ State ownership } & $\begin{array}{l}\text { Definition: The extent to which the state owns the shares } \\
\text { of the firm (Le and O'Brien, 2010). } \\
\text { Measures: }\end{array}$ & & \\
\hline & $\begin{array}{l}\text { The percentage of state shareholdings to total } \\
\text { shares outstanding }\end{array}$ & 143 & 71 \\
\hline & Firm is controlled by the state (dummy) & 39 & 28 \\
\hline \multirow[t]{9}{*}{ Accounting performance } & $\begin{array}{l}\text { Definition: Any indicator of the financial performance of } \\
\text { the firm that is expressed in the form of an accounting- } \\
\text { based measure of firm profits. } \\
\text { Measures: }\end{array}$ & & \\
\hline & Return on equity (ROE) & 53 & 36 \\
\hline & Return on assets (ROA) & 113 & 77 \\
\hline & Return on sales (ROS) & 13 & 12 \\
\hline & Return on investment (ROI) & 4 & 8 \\
\hline & Earnings per share (EPS) & 4 & 11 \\
\hline & Profit margin & - & 2 \\
\hline & Profits & 32 & 12 \\
\hline & Sales growth & 6 & 27 \\
\hline \multirow[t]{6}{*}{ Market performance } & $\begin{array}{l}\text { Definition: Any indicator of the financial performance of } \\
\text { the firm that is expressed in the form of a market-based } \\
\text { measure of firm value. } \\
\text { Measures: }\end{array}$ & & \\
\hline & Stock performance & 10 & 34 \\
\hline & Abnormal stock returns & 4 & 4 \\
\hline & Market-to-book ratio & 47 & 36 \\
\hline & Tobin's Q & 104 & 31 \\
\hline & $\begin{array}{l}\text { Enterprise value (total debt plus market value of equity/ } \\
\text { EBIT) }\end{array}$ & - & 4 \\
\hline
\end{tabular}

variables harvested from the studies included in our meta-analysis. One author coded all effect sizes. A second rater (who is not an author) coded a subsample of 100 randomly selected effect sizes, after which we computed a chance agreement-corrected measure of interrater reliability (Cohen's [1960] kappa coefficient). With a value of 0.98, kappa signified high a high level of interrater agreement.

The distribution of years of the articles included in our study ranges from 1991 to 2011 for samples based on Pearson product-moment correlation (r), and from 1991 to 2008 for samples based on partial linear correlations $\left(r_{x y . z}\right)$. The period relies on the years the data were collected in the original studies. The proportion of SOEs among all sampled firms is 70 per cent. Consistent with recent conceptualization that modern SOEs tend to be hybrids (and not 100 per cent owned by the state) (Bruton et al., 2015), 
the mean state ownership among all sampled firms is 35.6 per cent. Our sample mainly includes firms from the Shanghai Stock Exchange (80 out of 84 papers) and Shenzhen Stock Exchange (77 out of 84 papers). Nine papers include Chinese firms listed on the Hong Kong Stock Exchange.

\section{Hedges and Olkin Meta-Analysis (HOMA) Procedure}

We used Hedges and Olkin (1985) meta-analysis (HOMA) to compute the metaanalytic mean correlation between corporate governance mechanisms and firm performance in China. HOMA calculates the meta-analytic mean correlation between two variables and the corresponding confidence interval (Lipsey and Wilson, 2001). The data used are effect sizes such as the Pearson product-moment correlation $r$ or the partial correlation coefficient $r_{x y . z}$. We employed both $r$ and $r_{x y . z}$. We used $r$ because it offers a scale-free measure of linear association. $r$ is a bivariate measure, which ignores the effect of other variables that researchers may use as controls in multivariate tests. We therefore also used $r_{x y . z}$, which is a unit-less measure computed from regression results. This makes partial correlations from one study readily comparable to partial correlations in another study (Doucouliagos and Ulubasoğlu, 2008). ${ }^{[2]}$ In our case, $r_{x y . z}$ captures the association between board independence, CEO duality, managerial incentives, and state ownership $(x)$ on the one hand and firm performance $(x)$ on the other hand, given a set of $n$ controlling variables $(z)^{[3]}$

When a study reported multiple measurements of the focal effect, we included all of them as part of our dataset. Monte Carlo simulations showed that procedures using the complete set of measurements outperform those representing each study by a single value in areas like parameter significance testing and parameter estimation accuracy (Bijmolt and Pieters, 2001). We used the random-effects HOMA for combining study estimates (Raudenbush and Bryk, 2002). To account for differences in precision across effect sizes, we weighted effect sizes by their inverse variance weight $w$ (Hedges and Olkin, 1985). ${ }^{[4]}$ We also used these weights to calculate the standard error of the mean effect size and its confidence interval. ${ }^{[5]}$

\section{Meta-Analytical Regression Analysis (Mara) Procedures}

Following Lipsey and Wilson (2001), we tested our hypotheses using meta-analytical regression analysis (MARA). In our MARA, the dependent variable was neither corporate governance variable nor firm performance, but an estimate of the associational strength of the focal relationship - the relationship between internal corporate governance mechanisms and firm performance - in a given sample. We used partial correlation coefficients $\left(r_{x y . z}\right)$ as our effect size estimates for the MARA procedure, which in this case capture the association between firm performance and corporate governance given a set of $n$ control variables. Like conventional multiple regression approaches, MARA analyses a linear regression model involving a set of predictors - in this case board independence, CEO duality, managerial incentives, and SOE ownership-firm performance relationship (i.e., measurement and study characteristics) - on the dependent variable (i.e., the effect size). We weighted these effect sizes by their inverse variance weight to account for differences in the precision of the information contained in them (Aguinis 
et al., 2011). In other words, the primary-level study effect sizes were regressed onto a set of predictors (moderators) of the relationship between board independence, CEO duality, managerial incentives, and state ownership on the one hand and firm performance on the other hand (Carney et al., 2011; Doucouliagos and Ulubasoğlu, 2008). Following current standards in the meta-analytic literature (Geyskens et al., 2009), we used random effects estimation methods in our MARA analyses, which are more conservative than conventional fixed effects methods. Specifically, this yielded the following regression equation:

$$
R_{i}=\mathrm{y}_{0}+\mathrm{y}_{\mathrm{m}} \mathrm{D}_{i}+\beta_{\mathrm{m}} \mathrm{S}_{i}+\varphi \mathrm{R}_{I}+u_{i}
$$

where $R_{i}$ is the partial correlation between internal corporate governance and firm performance, $y_{0}$ the constant term, $D$ a vector of measurement artefacts, $S$ a vector of study characteristics, $R$ the median year of the sample window, and $u_{i}$ the random component.

To control for the influence of measurement artefacts on effect sizes, we included in the $\mathrm{D}$ vector the control variables. Specifically, to test for the moderating effect of focal variable operationalizations, we added dummy variables indicating whether firm performance was measured as accounting (0) or as market (1) performance, and coded for two types of managerial incentives CEO pay (1) and managerial ownership (0). To test for the moderating effect of methodological artefacts, we controlled for the 'file drawer problem' (Rosenthal, 1979), by including a dummy variable denoting whether a study was published (1) or not (0). Finally, we included a dummy variable, indicating whether a given effect size was based on panel (1) or cross-sectional (0) data and whether the sample controlled for SOE ownership (1) or not (0). To test our hypotheses, we included median year of sample window to test for the possibility that the relationship weakened or strengthened over time.

As a robustness check, we measured the effect of market institutions on the effectiveness of corporate governance variables by collecting data on market capitalization of firms to GDP and stock market value to GDP. One of the unique benefits of MARA is that it allows for the modelling of such heterogeneity with the help of data that were not part of the primary studies involved. In our case, we collected additional stock market variables to explain heterogeneity across effect sizes.

\section{RESULTS}

\section{HOMA Results}

Tables III-V show the $r_{x y . z}$-based and $r$-based HOMA results related to the corporate governance-firm performance relationship. In addition to the meta-analytic mean, we report the number of samples $(\boldsymbol{K})$, firm observations $(\mathcal{N})$, standard error of the mean effect size $(S E), 95$ per cent confidence interval around the meta-analytic mean (CI 95 per cent), the Hedges and Olkin (1985) chi-square test for heterogeneity (Q), and $I^{2}$ scale-free index of heterogeneity. Table III shows the relationship between our 


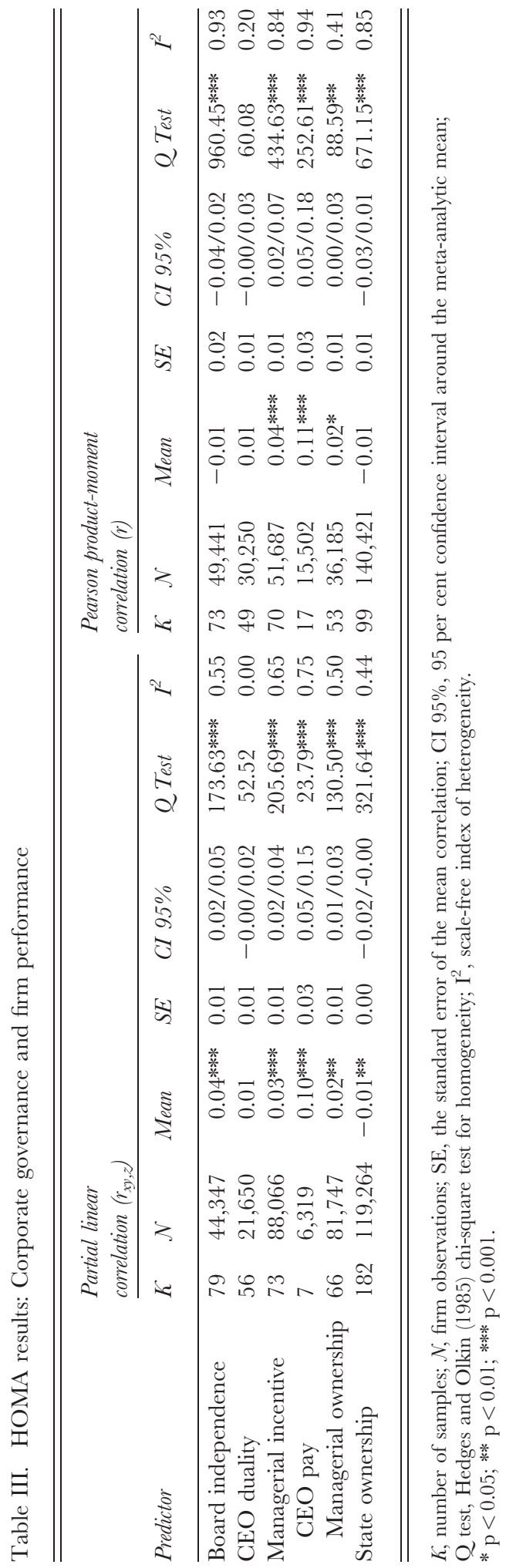

(C) 2017 John Wiley \& Sons Ltd and Society for the Advancement of Management Studies 


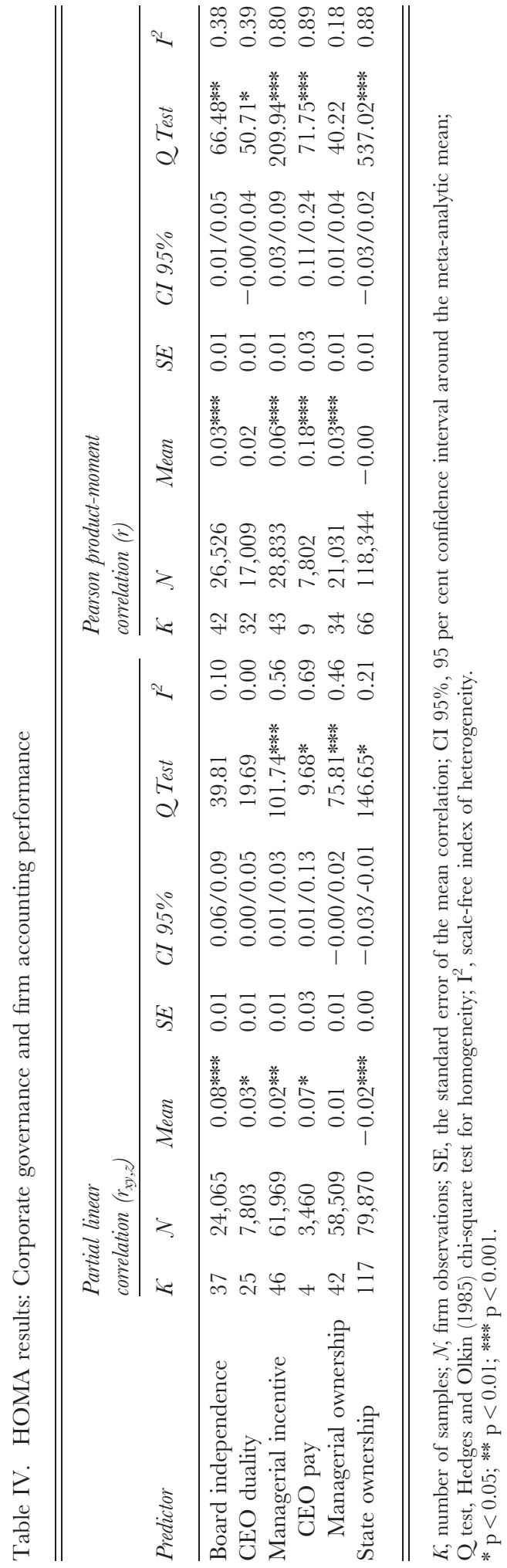




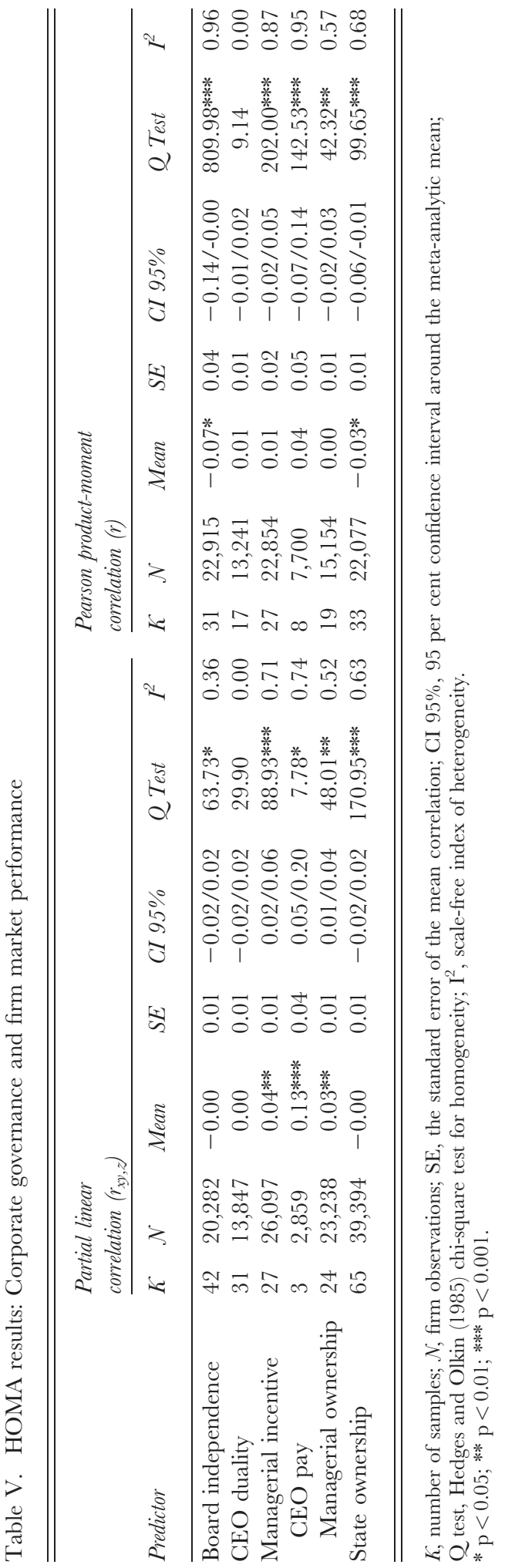

(C) 2017 John Wiley \& Sons Ltd and Society for the Advancement of Management Studies 
independent variables and firm performance, and Tables IV and V distinguish between accounting and market performance measures, respectively.

In Table III, the mean $r_{x y . z}$ of the relationship between board independence and firm performance is positive and significant $\left(r_{x y .}\right.$-based mean effect size $\left.=0.04, p<0.001\right)$, thus supporting Hypothesis la. The significance of the relationship disappears in $r$-based HOMA results $(r$-based mean effect size $=-0.01$, ns), which may be due to the difference in sample sizes and the influence of control variables used in $r_{x y . z}$-based analysis. We also find different results when we distinguish between accounting-based and market-based measures of firm performance. In Table IV, the relationship between board independence and accounting performance is positive and significant $\left(r_{x y . z}\right.$-based mean effect size $=0.08, p<0.001 ; r$-based mean effect size $=0.03, p<0.001)$. However, in Table $\mathrm{V}$, there is no or negative significant association between board independence and market performance $\left(r_{x y . z}\right.$-based mean effect size $=-0.00$, ns; $r$-based mean effect size $=-0.07, p<0.05)$. Overall, the mean size effects indicate a modestly positive (but occasionally insignificant) association between board independence and firm performance in the Chinese context, generally supporting Hypothesis la.

Our results regarding CEO duality are insignificant. In Table III, the overall mean $r_{x y . z}$ and $r$ of the focal relationship are, respectively, 0.01 and 0.01 - both insignificant. Tables IV and V also show no clear significant relationship between CEO duality and accounting and market performances, except for a positive relationship in regards to the mean $r_{x y . z}$ of the relationship between CEO duality and accounting performance (mean effect size $=0.03, p<0.05)$. Taken together, our results show little empirical support for a positive or negative relationship between $\mathrm{CEO}$ duality and firm performance. In other words, Hypothesis 2a is not supported.

Table III also reports the relationship between managerial incentives and firm performance. We find support for this effect for overall firm performance $\left(r_{x y}\right.$. $z$-based mean effect size $=0.03, p<0.001 ; r$-based mean effect size $=0.04, p<0.001)$. In Table IV, there is a positive and significant correlation between managerial incentives and accounting performance $\left(r_{x y . z}\right.$-based mean effect size $=0.02, p<0.01 ; r$-based mean effect size $=0.06, p<0.001)$. In Table $\mathrm{V}$, the correlation between managerial incentives and market performance is positive and significant only for $r_{\mathrm{xy} . \mathrm{z}}$-based results (mean effect size $=0.04, p<0.01)$. Overall, these results support Hypothesis 3a.

We further distinguish between CEO pay and managerial ownership to have a more nuanced understanding of the effect of managerial incentives on firm performance. According to our HOMA results in Tables III-V, the relationship between CEO pay and firm performance is both positive and significant (except for the relationship between CEO pay and market performance based on $r_{x y . z}$ ). Table III also illustrates a positive and significant relationship for managerial ownership based on partial linear correlation results (mean effect size $=0.02, p<0.01$ ) and on $r$-based results (mean effect size $=0.02, p<0.05)$. Taken together, results in Tables IV and V show modest support for a positive relationship.

Finally, we report the relationship between state ownership and firm performance. The results show that state ownership is either insignificantly related to or negatively significantly related to firm performance. The mean $r_{x y . z}$ of the focal relationship is -0.01 , and the confidence interval does not include zero, indicating that more state ownership 
has a negative and significant effect on performance. The $r$-based statistics reported in the right-hand panel of Table III show a slightly different result. While the mean is still -0.01 , the confidence interval does include zero. Overall, we find a modestly negative (but occasionally insignificant) association between state ownership and firm performance, thus supporting Hypothesis 4a.

We perform four robustness checks. First, we use firm-year observations instead of firm observation as a robustness test for the HOMA results and completed separate artefact-corrected meta-analytic methods (ACMA) (Hunter and Schmidt, 2004), shown in Tables VI and VII respectively. Results based on firm-year observations and ACMA are similar to those of the Hedges and Olkin-type meta-analysis and thus support our findings. Second, we conduct a one-sample removed analysis to assess the influence of each individual sample on the HOMA analysis (Borenstein et al., 2009). Results are broadly similar to those in Table III. Third, we perform additional HOMA analyses excluding nine and three potential outliers based on Cook's distance analysis (Cook, 1979) for the managerial ownership-firm performance and state ownership-firm performance relationships, respectively, both based on $r_{x y . z}$. We find similar results to those obtained in Tables III-V.

Fourth, we perform a triangulation method to test for potential publication bias in our HOMA analyses (Harrison et al., 2017). This method consists of three tests: (1) Duval and Tweedie's (2000) trim and fill, (2) cumulative meta-analysis (Borenstein et al., 2009), and (3) selection models (Hedges and Vevea, 2005). Results show the absence of publication bias in our results. We find similar results to those presented in Table III. Finally, we rely on hierarchical linear models meta-analysis (HILMMA) (Raudenbush and Bryk, 2002) to rule out the possibility that stochastic dependencies between multiple effect sizes harvested from a single primary study biased our HOMA estimates. The corrected mean correlations are the same as the uncorrected mean correlations between corporate governance and firm performance in Table III. This diagnostic test thus shows that stochastic interdependencies between effect sizes derived from similar studies do not influence our results.

\section{Temporal Effects}

Our Hypotheses 1b, 3b, and 4b predict that the relationship between board independence, managerial incentives, and state ownership on the one hand and firm performance on the other hand would become more strongly positive over time. Hypothesis 2b suggests that the relationship between CEO duality and firm performance would become more strongly negative over time. Tables VIII-X present the MARA results on the partial correlation between internal corporate governance mechanisms and firm performance. Table VIII includes median year of sample window to test for the possibility that the relationship weakens or strengthens over time, whereas Tables IX and X examine the moderating effect of the level of stock market capitalization and the level of stock market value on the effectiveness of internal governance mechanisms. Thus, we not only examine how the relationship changes over time, but also study how the development of market institutions influences this relationship. 


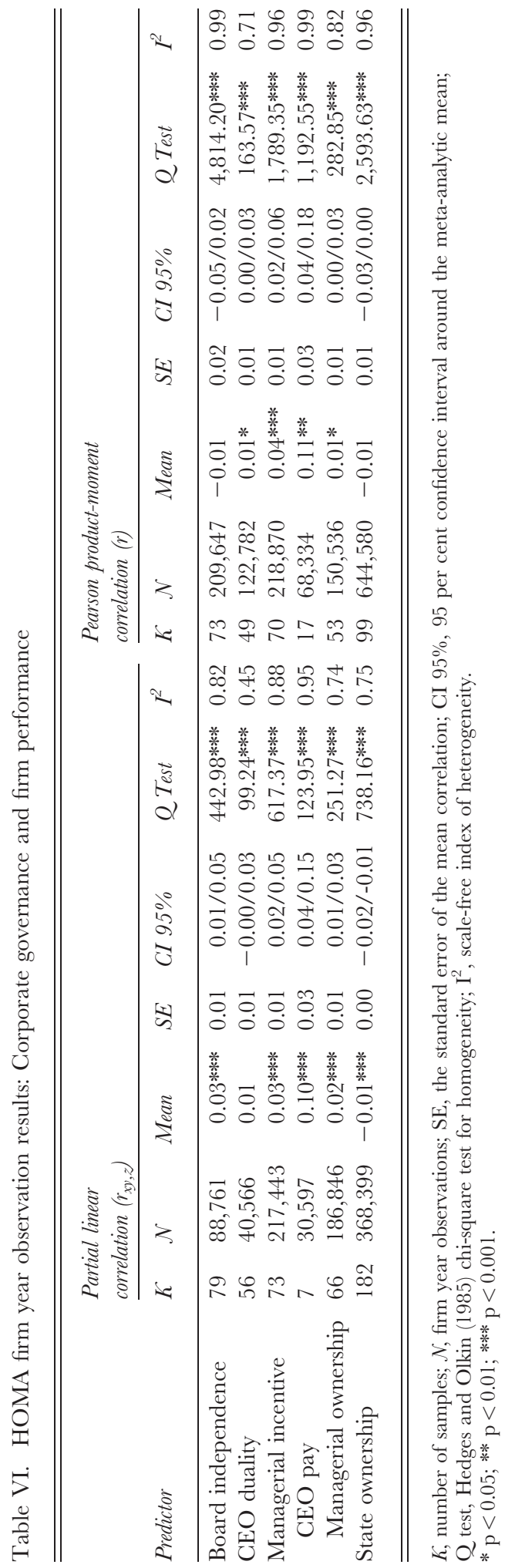




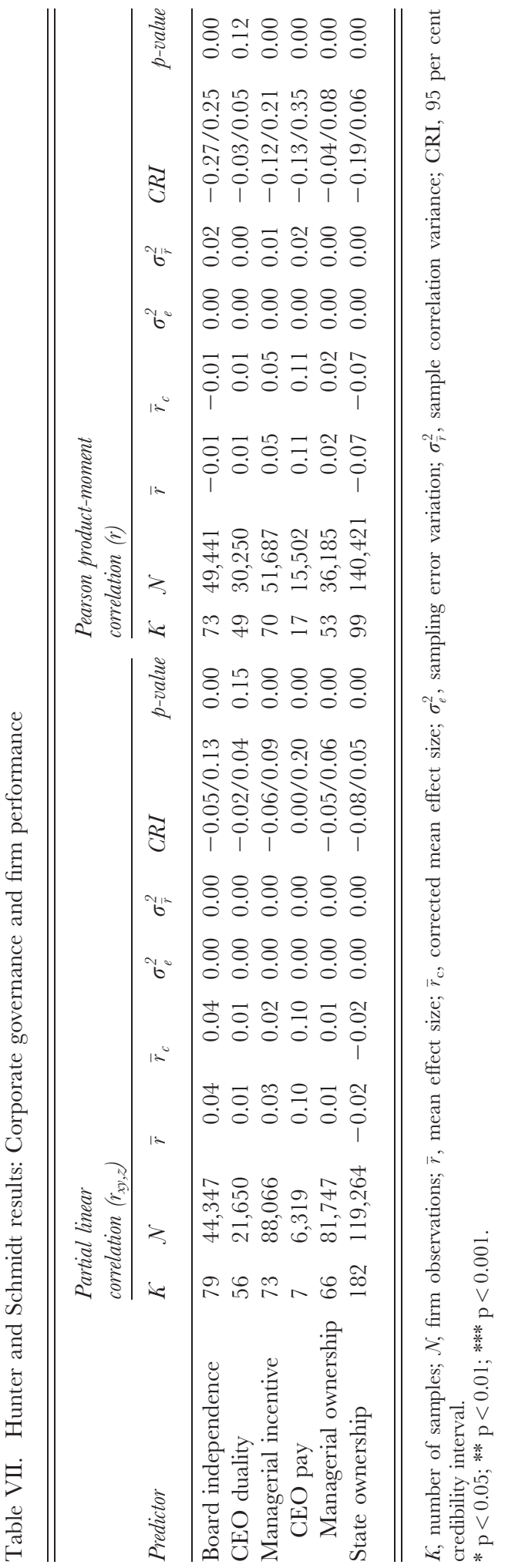

(C) 2017 John Wiley \& Sons Ltd and Society for the Advancement of Management Studies 
Table VIII. Results of mixed-effects WLS regression partial correlation results

\begin{tabular}{|c|c|c|c|c|}
\hline & $\begin{array}{l}\text { Model } 1 \\
\text { Board } \\
\text { independence- } \\
\text { firm performance }\end{array}$ & $\begin{array}{l}\text { Model } 2 \\
\text { CEO } \\
\text { duality-firm } \\
\text { performance }\end{array}$ & $\begin{array}{l}\text { Model } 3 \\
\text { Managerial } \\
\text { incentives-firm } \\
\text { performance }\end{array}$ & $\begin{array}{l}\text { Model } 4 \\
\text { SOE-firm } \\
\text { performance }\end{array}$ \\
\hline Constant & $-11.06(4.53)^{*}$ & $2.30(5.56)$ & $6.64(2.73)^{*}$ & $-8.44(2.98)^{* *}$ \\
\hline \multicolumn{5}{|l|}{$\begin{array}{l}\text { Corporate governance } \\
\text { predictors }\end{array}$} \\
\hline $\begin{array}{l}\text { CEO pay } \\
\text { Managerial ownership (ref) }\end{array}$ & & & $0.10(0.02)^{* * * *}$ & \\
\hline \multicolumn{5}{|l|}{ Performance predictors } \\
\hline $\begin{array}{l}\text { Market performance } \\
\text { Accounting performance (ref) }\end{array}$ & $-0.09(0.02)^{* * *}$ & $-0.03(0.02)$ & $0.00(0.01)$ & $0.01(0.01)$ \\
\hline \multicolumn{5}{|l|}{ Methodological predictors } \\
\hline Published & $-0.03(0.02)$ & $0.04(0.03)$ & $-0.01(0.01)$ & $-0.01(0.01)$ \\
\hline Panel & $0.02(0.02)$ & $-0.00(0.02)$ & $-0.11(0.02)^{* * *}$ & $0.01(0.01)$ \\
\hline $\begin{array}{l}\text { Original regression controlled } \\
\text { by } \mathrm{SOE} \%\end{array}$ & $0.01(0.01)$ & $0.04(0.02)$ & $0.00(0.01)$ & \\
\hline Median year of effect size & $0.01(0.00)^{*}$ & $-0.00(0.00)$ & $-0.00(0.00)^{*}$ & $0.00(0.00)^{* *}$ \\
\hline$R^{2}$ & 0.42 & 0.16 & 0.55 & 0.06 \\
\hline$K$ & 79 & 56 & 73 & 182 \\
\hline
\end{tabular}

$* \mathrm{p}<0.05 ; * * \mathrm{p}<0.01 ; * * * \mathrm{p}<0.001$

Table IX. Results of mixed-effects WLS regression partial correlation results and stock market capitalization

\begin{tabular}{|c|c|c|c|c|}
\hline & $\begin{array}{l}\text { Model } 1.1 \\
\text { Board } \\
\text { independence-- } \\
\text { firm performance }\end{array}$ & $\begin{array}{l}\text { Model } 2.1 \\
\text { CEO } \\
\text { duality firm } \\
\text { performance }\end{array}$ & $\begin{array}{l}\text { Model } 3.1 \\
\text { Managerial } \\
\text { incentives-firm } \\
\text { performance }\end{array}$ & $\begin{array}{l}\text { Model } 4.1 \\
\text { SOE-firm } \\
\text { performance }\end{array}$ \\
\hline Constant & $0.08(0.04)^{*}$ & $0.06(0.03)^{*}$ & $0.10(0.02)^{* *}$ & $-0.04(0.02)^{*}$ \\
\hline $\begin{array}{l}\text { Corporate governance predictors } \\
\text { CEO pay } \\
\text { Managerial ownership (ref) }\end{array}$ & & & $0.10(0.02)^{* * *}$ & \\
\hline $\begin{array}{l}\text { Performance predictors } \\
\text { Market performance } \\
\text { Accounting performance (ref) }\end{array}$ & $-0.08(0.02)^{* * * *}$ & $-0.02(0.02)$ & $0.01(0.01)$ & $0.01(0.01)$ \\
\hline Methodological predictors & & & & \\
\hline Published & $-0.02(0.02)$ & $-0.03(0.02)$ & $-0.02(0.01)$ & $-0.01(0.01)$ \\
\hline Panel & $0.01(0.02)$ & $-0.02(0.02)^{*}$ & $-0.11(0.02)^{* * *}$ & $0.02(0.01)$ \\
\hline $\begin{array}{l}\text { Original regression } \\
\text { controlled by SOE \% }\end{array}$ & $0.01(0.01)$ & $0.03(0.02)$ & $0.01(0.01)$ & \\
\hline Stock market capitalization & $0.00(0.00)$ & $-0.00(0.00)^{* *}$ & $0.00(0.00)$ & $0.00(0.00)^{*}$ \\
\hline$R^{2}$ & 0.36 & 0.30 & 0.52 & 0.04 \\
\hline$\kappa$ & 79 & 56 & 73 & 182 \\
\hline
\end{tabular}

$* \mathrm{p}<0.05 ; * * \mathrm{p}<0.01 ; * * \mathrm{p}<0.001$ 
Table X. Results of mixed-effects WLS regression partial correlation results and stock market value

\begin{tabular}{|c|c|c|c|c|}
\hline & $\begin{array}{l}\text { Model } 1.2 \\
\text { Board } \\
\text { independence- } \\
\text { firm performance }\end{array}$ & $\begin{array}{l}\text { Model } 2.2 \\
\text { CEO } \\
\text { duality-firm } \\
\text { performance }\end{array}$ & $\begin{array}{l}\text { Model } 3.2 \\
\text { Managerial } \\
\text { incentives-firm } \\
\text { performance }\end{array}$ & $\begin{array}{l}\text { Model } 4.2 \\
\text { SOE-firm } \\
\text { performance }\end{array}$ \\
\hline Constant & $0.08(0.03)^{*}$ & $0.07(0.03)^{*}$ & $0.07(0.03)^{* *}$ & $-0.03(0.02)^{*}$ \\
\hline $\begin{array}{l}\text { Corporate governance predictors } \\
\text { CEO pay } \\
\text { Managerial ownership (ref) }\end{array}$ & & & $0.10(0.02)^{* * *}$ & \\
\hline $\begin{array}{l}\text { Performance predictors } \\
\text { Market performance } \\
\text { Accounting performance (ref) } \\
\text { Methodological predictors }\end{array}$ & $-0.09(0.02)^{* * * *}$ & $-0.03(0.02)$ & $0.00(0.01)$ & $0.01(0.01)$ \\
\hline $\begin{array}{l}\text { Published } \\
\text { Panel } \\
\text { Original regression } \\
\quad \text { controlled by SOE \% }\end{array}$ & $\begin{array}{l}-0.02(0.02) \\
0.01(0.02) \\
0.01(0.01)\end{array}$ & $\begin{array}{c}-0.04(0.02) \\
-0.01(0.02) \\
0.04(0.02)\end{array}$ & $\begin{array}{c}-0.02(0.01) \\
-0.11(0.02)^{* * *} \\
0.01(0.01)\end{array}$ & $\begin{array}{c}-0.02(0.01) \\
0.02(0.01)\end{array}$ \\
\hline $\begin{array}{l}\text { Stock market value } \\
R^{2} \\
K\end{array}$ & $\begin{array}{c}0.00(0.00) \\
0.37 \\
79\end{array}$ & $\begin{array}{c}-0.00(0.00)^{*} \\
0.26 \\
56\end{array}$ & $\begin{array}{c}0.00(0.00)^{*} \\
0.54 \\
73\end{array}$ & $\begin{array}{c}0.00(0.00)^{*} \\
0.05 \\
182\end{array}$ \\
\hline
\end{tabular}

$* \mathrm{p}<0.05 ; * \mathrm{p}<0.01 ; * * * \mathrm{p}<0.001$

In Model 1 of Table VIII, we examine whether the relationship between board independence and firm performance becomes more positive over time. We find support for this effect as the median year of effect size is positive and significant $(b=0.01, p<0.05)$. In Tables IX and X, when we examine the effect of both stock market capitalization and stock market value, we find no significant results. Overall, we observe that the relationship between board independence and firm performance becomes more positive over time, thus supporting Hypothesis $1 \mathrm{~b}$.

In Model 2 of Table VIII, we test whether the effect of CEO duality becomes more negative over time. As the effect size is not significant, we find no support for Hypothesis $2 \mathrm{~b}$. However, negative and significant results emerge when we examine the effect of stock market capitalization $(b=-0.00, p<0.01)$ and stock market value $(b=-0.00$, $p<0.05)$ in Tables IX and $\mathrm{X}$, respectively. Thus, according to the stock market indicators, the negative correlation between CEO duality and firm performance is stronger over time, supporting Hypothesis $2 \mathrm{~b}$.

In Model 3 of Table VIII, we report whether the relationship between managerial incentives and firm performance becomes more positive over time. In contrast to Hypothesis $3 \mathrm{~b}$, the median year of the effect size is negative and significant $(b=-0.00, p<0.05)$. However, we report insignificant effect of stock market capitalization $(b=0.00$, ns) and positive and significant effect of stock market value $(b=0.00, p<0.05)$ in Tables IX and $\mathrm{X}$, respectively. These findings fail to support Hypothesis $3 \mathrm{~b}$. In fact, the relationship between managerial incentives and firm performance becomes weaker over time. Yet, when we consider stock market value, the relationship becomes modestly stronger. 
Finally, in Model 4 of Table VIII, we find strong support for Hypothesis 4b. Thus, the relationship between state ownership and firm performance becomes more positive over time $(b=0.00, p<0.01)$. Tables IX and $\mathrm{X}$ also report positive and significant results for the effect of both stock market capitalization $(b=0.00, p<0.05)$ and stock market value $(b=0.00, p<0.05)$, respectively.

\section{DISGUSSION}

\section{Contributions}

Motivated by an intense scholarly and practical interest in understanding whether standard corporate governance mechanisms work in China, this study makes two contributions. First, we join the debate on how 'good' corporate governance principles affect firm performance in the Chinese context with quantitative evidence. Previous metaanalyses either deal with developed economies (primarily the United States) (Dalton et al., 1998) or Asia in general (Heugens et al., 2009; Van Essen et al., 2012b). Through advanced meta-analytical techniques, we provide a detailed quantitative review for monitoring and alignment mechanisms as well as state ownership and their relationships to firm performance in China, thus tackling an important but previously unaddressed research gap (Combs et al., 2011; Eden, 2002). Undertaking the first meta-analysis on the corporate governance literature focusing on China, our efforts are timely and valuable as meta-analytic techniques help provide a comprehensive and quantitative assessment of empirical studies within a growing field.

Second, going above and beyond a static perspective (such as whether certain governance mechanisms are effective or ineffective), our findings contribute to corporate governance research by showing that internal monitoring and alignment mechanisms can help improve firm outcomes, especially when accompanied by improvements in market institutions. Although standard corporate governance codes seem to be increasingly adopted throughout the world, their implications are usually different as the surrounding institutions are differentially configured (Haxhi and Aguilera, 2017). The corporate governance literature has begun to integrate the 'context matters' perspective, yet little has been said about how the changes in the context matter. Given the dynamic reality in which firms compete, we need to consider the role of space and time in conjunction with each other (Ancona et al., 2001; Kim et al., 2010; Shi et al., 2012). Inspired by Peng (2003, 2004), we believe our temporal approach is a critical extension to the literature because it helps us understand the dynamic performance and convergence effects of these new governance practices.

China's dynamic institutional context specifically enables us to account for the role of time as a proxy for the changes in the external environment that influences the outcomes of internal corporate governance mechanisms. This study, therefore, leverages a dynamic institution-based view to provide a more comprehensive theoretical account of the link between internal corporate governance mechanisms and firm performance (Banalieva et al., 2015; Meyer and Peng, 2016; Peng, 2004). Since institutional dynamism directly influences the growth and performance of firms (Peng and Heath, 1996), 
Table XI. Cumulative evidence on the relationship between governance mechanisms and firm performance

\begin{tabular}{|c|c|c|c|c|}
\hline Meta-analytic studies & Context & $\begin{array}{l}\text { Board } \\
\text { independence }\end{array}$ & $\begin{array}{l}\text { CEO } \\
\text { duality }\end{array}$ & $\begin{array}{l}\text { Managerial } \\
\text { incentives }\end{array}$ \\
\hline Dalton et al. (1998) & US firms & $\begin{array}{l}\text { Near zero } \\
\quad \text { relationship }\end{array}$ & $\begin{array}{l}\text { Near zero } \\
\quad \text { relationship }\end{array}$ & - \\
\hline Wagner et al. (1998) & US firms & $\begin{array}{l}\text { Positive } \\
\quad \text { relationship }\end{array}$ & - & - \\
\hline Tosi et al. (2000) & US firms & - & - & $\begin{array}{l}\text { Near zero } \\
\quad \text { relationship }\end{array}$ \\
\hline Van Essen et al. (2012a) & $\begin{array}{c}\text { Firms from } 29 \\
\text { countries } \\
\text { worldwide }\end{array}$ & - & - & $\begin{array}{l}\text { Modest positive } \\
\text { relationship }\end{array}$ \\
\hline Van Essen et al. (2012b) & Asian firms & $\begin{array}{l}\text { Near zero } \\
\quad \text { relationship }\end{array}$ & $\begin{array}{l}\text { Near zero } \\
\quad \text { relationship }\end{array}$ & - \\
\hline Our study & Chinese firms & $\begin{array}{l}\text { Positive } \\
\text { relationship, } \\
\text { which becomes } \\
\text { stronger over time }\end{array}$ & $\begin{array}{l}\text { Near zero } \\
\text { relationship }\end{array}$ & $\begin{array}{l}\text { Positive } \\
\text { relationship, } \\
\text { which becomes } \\
\text { weaker over time }\end{array}$ \\
\hline
\end{tabular}

it is central to corporate governance research, which should be more fully integrated with time-based research (Shi et al., 2012).

\section{Theory and Context}

While our study is from a particular institutional context, our findings complement other meta-analytic reviews by specifically shedding light on the temporal role of institutional reforms. The idiosyncrasies of the Chinese institutional context can create challenges in applying our findings to broader contexts, yet they also reveal how some of the unique elements such as social priorities accompany the formation of arm's-length codes such as boards' requirement to reveal director dissent (Ma and Khanna, 2016). Therefore, as illustrated in Table XI, our study complements the findings of the previous metaanalyses by leveraging the increasing empirical attention to corporate governance research in China. Existing research on the value effects of monitoring and alignment mechanisms, in the aggregate, finds inconclusive results even in developed economies such as the USA (Dalton and Dalton, 2011; Erkens et al., 2012). For example, Dalton et al. (1998) find no evidence of a substantive relationship based on 54 empirical studies of board composition (inside/outside ratio) and 31 empirical studies of CEO duality. Wagner et al. (1998) report that the greater presence of both outside directors and inside directors is associated with higher firm performance. Tosi et al. (2000) fail to find a significant relationship between firm performance and executive pay, and Van Essen et al. (2012a) report a modest correlation between firm performance and executive pay that varies depending on the level of institutional development in a given country. In comparison to the overall inconclusive findings of similar studies in different contexts, we 


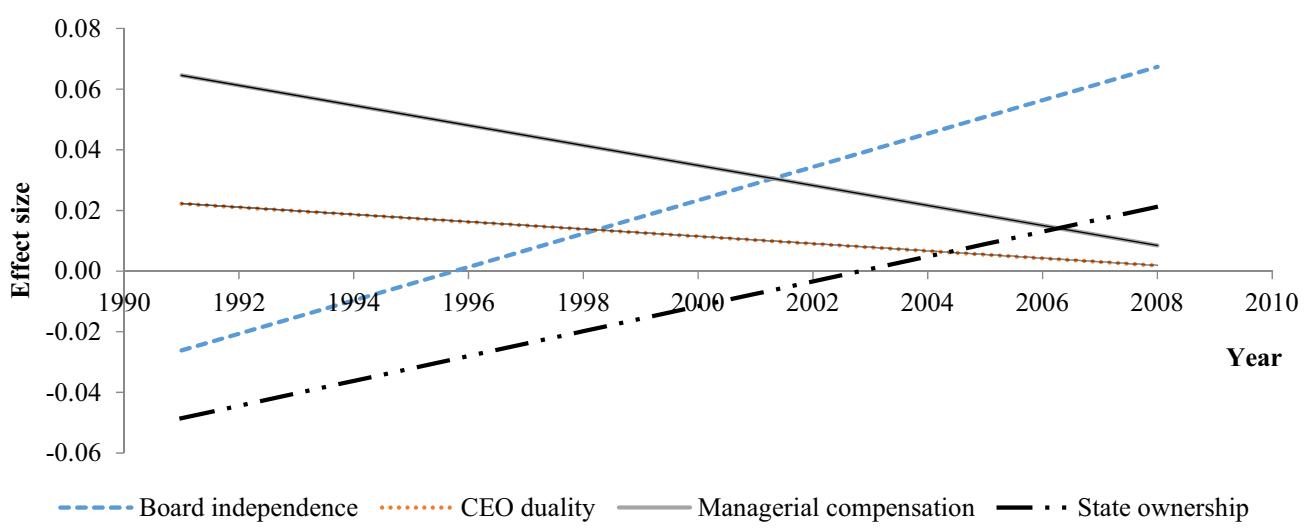

Figure 1. Effect sizes versus time [Colour figure can be viewed at wileyonlinelibrary.com]

find relatively strong support for our hypotheses in China concerning board independence and managerial incentives.

Understanding the role of institutions not only involves exploring contextual differences, but also requires integrating the stages of institutional transitions. The dynamic institutional transitions in China enable us to incorporate time to have a finer-grained understanding of how stages matter in the institutionalization of corporate governance codes and their relationship to firm performance over time. Figure 1 illustrates the trend of the four internal corporate governance mechanisms based on their effect sizes and the time period of our studies. Specifically, we observe that the predicted positive significant correlation between board independence and firm performance and the predicted negative correlation between $\mathrm{CEO}$ duality and firm performance prevails over time. The weight of evidence regarding board independence indicates that as market reforms deepen, labour markets for directors may become more efficient, ultimately sensitizing outside directors towards the maintenance of their reputation and credibility (Jiang et al., 2016). However, our findings do not suggest a significant negative relationship between $\mathrm{CEO}$ duality and firm performance. While the drawbacks of CEO duality have been extensively discussed, there is still a general lack of empirical evidence regarding its net effect not only from emerging economies (Peng et al., 2010), but also from developed economies (Dalton et al., 2007). We must therefore interpret our findings with caution (Dalton and Dalton, 2011). Specifically, in the Chinese context, the effect of unity of command and efficient decision-making ability may counterbalance the importance of effective oversight, given the relatively turbulent business environment (Peng et al., 2007, 2010). However, when we consider stock market indicators, we observe that the effect of CEO duality on firm performance becomes more negative over time, which may indicate an increasing sensitivity to market signals. Overall, our findings reflect the increasing discipline that Chinese firms face not only internally but also externally, as the role of external corporate governance mechanisms (such as labour and capital markets) in controlling the self-serving behaviour of managers become more visible.

In contrast to our predictions, we find significant negative results for managerial incentives in our temporal analyses (Figure 1). The managerial incentive line is downward 
slopping yet still positive, indicating a positive relationship, albeit one that is less effective over time. These mixed results may stem from two factors. First, CEO compensation may still be subject to intervention from officials in the process of mitigating the potential public outrage against high levels of CEO pay (Firth et al., 2010). Second, compensation decisions may be subject to legitimacy concerns of firms that may potentially hurt the payperformance relationship. For example, following the recommendations of the China Securities Regulatory Commission (CSRG), Chinese listed firms set up compensation committees, which signal them to be willing to 'go the extra mile' in order to ensure corporate control of CEO compensation (Markoczy et al., 2013, p. 1368). Therefore, our findings indicate that while China's corporate governance reforms have been helpful in aligning managerial interests with shareholders, the reforms have a great deal of room to deepen further (Hu and Zhou, 2008; Wang and Judge, 2012).

Finally, our findings regarding state ownership support the recent work that highlights SOEs as competitive firms (Bruton et al., 2015; Peng et al., 2016). Our findings indicate a slightly negative relationship between state ownership and firm performance, reflecting that many SOEs still underperform. As seen in Figure 1, we also observe that the relationship becomes more positive over time. One reason behind this finding may be that SOEs have been central to China's market reforms and, thus, are increasingly regarded as strategic players in the economy (Peng et al., 2016). Over time, market reforms have facilitated SOEs' market orientation and performance focus (Huang et al., 2017).

A possible explanation for our findings may be the co-evolution of market reforms and the adoption of standard corporate governance principles that over time complement each other (Haxhi and Aguilera, 2017). Specifically, given the more gradual nature of China's institutional transitions (as opposed to the more abrupt transitions in Central and Eastern Europe), the temporal effects of introducing 'good' governance outcomes are more likely to be observed. Some scholars indeed argue that gradual reforms are better because they allow for 'maximum adjustment and minimal stress' (Banalieva et al., 2015, p. 1359). Partial support may also stem from China's hybrid state between central planning and market competition. Such hybrid state highlights the role of newly adopted corporate governance mechanisms in controlling the self-serving behaviour of managers, whose mind-set is evolving from relationship-based to more market-oriented. It is therefore possible that in the future stages of the market reforms, unique institutional configurations will emerge that may alter the dynamics between 'good' corporate governance principles and firm performance.

Furthermore, although China offers an interesting context, there is often a suspicion that corporate governance reforms are merely window-dressing (Conyon and He, 2011). Therefore, one possible reason behind insignificant findings is that some firms may rely on certain 'good' corporate governance principles to signal that their internal mechanisms are scrupulous (Markoczy et al., 2013). Symbolic management effect may be particularly heightened in China, as major institutional transitions tend to create abundant grey areas in socially accepted rules and norms that increase firms' concerns for legitimacy (Markoczy et al., 2013; Peng, 2004). As such, adopting certain symbolic principles within their governance structure may signal conformity to institutional rules and norms in form, but not necessarily in substance (Westphal and Graebner, 2010). 


\section{Practical Implications}

Throughout market reforms, Chinese practitioners and policymakers have sometimes charged ahead in the absence of solid empirical support for certain governance mechanisms (Peng, 2004, p. 468). Consolidating numerous studies and going beyond their findings, our meta-analysis offers unique insights for practitioners and policy makers. For policy makers, the weight of evidence suggests that 'good' corporate governance practices are indeed associated with better performance for Chinese firms. Temporal results further indicate, albeit partially, a stronger link on the importance of standard monitoring and alignment mechanisms. Our results primarily highlight the complementary role of good policies that promote steady institutional reforms and stronger financial markets. More efforts along these dimensions are therefore called for.

Besides having ramifications for policymakers, our findings have significant implications for managers. Corporate surveys show Chinese executives' agreement that better governance helps their firms in many ways, including access to capital, shareholder rights protection, and decision-making (Deloitte, 2010). Our findings on the lack of relationship between CEO duality and firm performance call for caution regarding proposed reform efforts to legally mandate the separation of the positions of board chair and CEO. In other words, our findings do not support criticisms that advocate the phasing out of CEO duality. Our findings on SOE performance are also critical, given the scholarly and practitioner calls to pay special attention to SOEs that bounce back as significant players not only in domestic but also global markets (Bruton et al., 2015).

It is likely that with economic growth and accompanying institutional reforms, Chinese executives are paying more attention to achieving higher returns. The stock market indicators, albeit partially, support this as we observe a stronger correlation of 'good' corporate governance principles such as managerial incentives or the separation of CEO and board chair positions with stock market indicators over time. The future ramifications of these findings would be that as market reforms deepen, Chinese firms need to take internal corporate governance principles more seriously to improve both market and financial performance. Indeed, some of the board requirements such as disclosing independent directors' dissent during board meetings go beyond the global standards of 'good' corporate governance. They offer scholars a rare window to explore the inner workings of corporate boards in China (Ma and Khanna, 2016). Such dynamics and the hybrid nature of the institutional context increasingly implore Chinese executives to reevaluate the balance between the formal requirements that mandate transparency and the informal norms that value social exchange and reciprocity. Overall, we argue that given the increasing integration with the world economy and exposure to international competition (Hoskisson et al., 2013; Mutlu et al., 2015), Chinese firms that operate by global standards of governance may have higher chances of better performance.

\section{Limitations and Future Research}

Our findings indicate a need to more closely incorporate time in corporate governance research especially in dynamic contexts. However, a major challenge in temporal studies is that 'it is simply hard to do so' (Ancona et al., 2001, p. 647). For example, using a linear pattern is easier because we do not have the methodologies to capture more 
complex phenomenon. Meta-analysis also has its limitations. It is limited because the influence of time is modelled as a crude moderator effect (Combs et al., 2011) as we have done in our MARA (Van Essen et al., 2015). Our temporal window of the sample studies spans 18 years (1991-2008), which suggests that most of the samples concern Stage 2 (35 per cent) and Stage 3 (65 per cent) of China's corporate governance reforms (see Table I). The median temporal split is around the year 2001. As such, our study essentially compares Stage 2 versus Stage 3, whereas Stage 1 marks the beginning of governance reforms in China. We believe that additional primary studies - especially studies that probe Stage 1 - may help capture longitudinal effects more effectively.

A potential avenue to integrate temporal dimension may be to compare different speeds of institutional transitions such as gradual versus rapid reforms to understand how the pace of market reforms affects the evolution of corporate governance mechanisms (Ancona et al., 2001). Future research may benefit from comparative studies in regions such as Central and Eastern Europe (Meyer and Peng, 2016). Another direction is to probe intra-regional (sub-national) institutional differences within China, which may add a new dimension of institutional dynamism (Peng and Lebedev, 2017).

Finally, beyond the explained scholarly and practical reasons, our choice of internal governance mechanisms is also driven by the availability of data. For example, although our variables are the most commonly used and central proxies of internal corporate governance mechanisms, there are still limitations regarding data availability on managerial incentives. Therefore, we include a dummy variable of whether managerial incentive is measured as CEO pay (1) or managerial ownership (0) in the MARA section. This limitation suggests a potential research gap that needs to be addressed in the future studies to have a better understanding of the nature of the alignment mechanisms and their link to firm outcomes in China. Other important corporate governance mechanisms such as firms' affiliation to business groups is also likely to be important (Carney et al., 2011). Future research may also integrate the role of ownership concentration and different types of ownership, which are critical characteristics of corporate governance in China, specifically by utilizing qualitative comparative techniques such as fuzzy sets (Misangyi and Acharya, 2014).

\section{GONGLUSION}

How has the impact of 'good corporate governance' principles on firm performance changed over time in China? In the absence of concrete evidence, China's uncertain institutional transitions make it very challenging to entertain such crucial questions, hence triggering significant scholarly and practitioner debate. Responding to this timely debate, our meta-analysis via the weight of evidence demonstrates that two major 'good corporate governance' principles advocating board independence and managerial incentives are indeed associated with better firm performance. However, we cannot find strong support for the criticisms against CEO duality. We also demonstrate how these effects evolve over the course of reforms. Advancing a dynamic institution-based view, our findings suggest that over time, board monitoring and state ownership are more positively associated with firm performance, whereas managerial incentives lose their significance. In conclusion, as China becomes the second largest economy in the world, 
corporate governance in China has become a particularly fascinating ground on which scholars can explore the dynamic effects of market reforms and institutional transitions. Our paper propels such endeavours to new heights.

\section{AGKNOWLEDGMENTS}

This article grows out of essay 3 of Mutlu's dissertation research completed at UT Dallas. We thank Greg Dess, Svetlana Flankova, Seung-Hyun Lee, Omar el Nayal, John Prescott (Associate Editor), Jun Xia, and three reviewers for constructive guidance. Earlier versions of this article were presented at UT Dallas as well as at the Academy of International Business (Bangalore, June 2015), Asia Academy of Management (Kitakyushu, June 2017), International Association for Chinese Management Research (Hangzhou, June 2016), and Strategic Management Society (Hong Kong, December 2016). This research has been supported by Coles College of Business at Kennesaw State University; the Jindal Chair at UT Dallas; and Universidad Adolfo Ibáñez Business School. We also acknowledge the financial support of CONICYT and the project Fondecyt Iniciación en Investigación 11150001.

\section{NOTES}

[1] In this article, China refers to mainland China and does not include Hong Kong, Macau, and Taiwan.

[2] The partial correlation coefficient is calculated as follows: $\sqrt{\left(\mathrm{t}^{2} /\left(\mathrm{t}^{2}+\mathrm{df}\right)\right)}$, where $t$ is the $\mathrm{t}$-statistic and $\mathrm{df}$ represents the degrees of freedom. Because this formula will always produce positive numbers, it is necessary to convert it to negative numbers if the regression coefficients are negative (Greene, 2008).

[3] To avoid upward bias and facilitate interpretation of the results, we did not use Fisher's $z$ scores (Schulze, 2004).

[4] $w$ is calculated as follows: $w_{i}=\frac{1}{s e_{i}^{2}+\hat{v}_{\theta}}$, where SE is the standard error of the effect size and $\hat{v}_{\theta}$ is the random effects variance component, which is in turn calculated as: s.e. $\left(z_{r}\right)=\frac{1}{\sqrt{n-3}}$, and the formula of random effect variance is: $\hat{v}_{\theta}=\frac{Q_{\mathcal{J}}-k-1}{\sum w-\left(\frac{\sum w^{2}}{\sum w}\right)}$.

[5] The meta-analytic mean is calculated as follows: $\overline{E S}=\frac{\sum(w \times E S)}{\sum w}$, with its standard error: $s e_{\overline{E S}}=\sqrt{\frac{1}{\sum w}}$, and with its $95 \%$ confidence interval computed as: Lower $=\overline{E S}-1.96\left(s e_{\overline{E S}}\right)$, Upper $=\overline{E S}+1.96\left(s e_{\overline{E S}}\right)$.

\section{REFERENGES}

References marked with an asterisk $(*)$ indicate studies included in the meta-analysis.

Adithipyangkul, P., Alon, I. and Zhang, T. (2011). 'Executive perks: Compensation and corporate performance in China'. Asia Pacific Fournal of Management, 28, 401-25.

Aguinis, H., Gottfredson, R. K. and Wright, T. A. (2011). 'Best-practice recommendations for estimating interaction effects using meta-analysis'. Fournal of Organizational Behavior, 32, 1033-43.

Allen, F., Qian, J. and Qian, M. (2005). 'Law, finance, and economic growth in China'. Journal of Financial Economics, 77, 57-116.

Ancona, D., Goodman, P. S., Lawrence, B. S. and Tushman, M. L. (2001). 'Time: A new research lens'. Academy of Management Review, 26, 645-53.

Bai, C. E. and Xu, L. X. (2005). 'Incentives for CEOs with multitasks: Evidence from Chinese stateowned enterprises'. Fournal of Comparative Economics, 33, 517-39.

*Bai, C. E., Liu, Q., Lu, J., Song, F. M. and Zhang, J. X. (2004). 'Corporate governance and market valuation in China'. Fournal of Comparative Economics, 32, 599-616.

Banalieva, E. R., Eddleston, K. A. and Zellweger, T. M. (2015). 'When do family firms have an advantage in transitioning economies? Toward a dynamic institution-based view'. Strategic Management fournal, 36, 1358-77. 
Bijmolt, T. H. A. and Pieters, R. G. M. (2001). 'Meta-analysis in marketing when studies contain multiple measurements'. Marketing Letters, 12, 157-69.

Borenstein, M., Hedges, L. V., Higgins, J. P. T. and Rothstein, H. R. (2009). Introduction to Meta-Analysis. Chichester: Wiley.

Bruce, A., Buck, T. and Main, B. (2005). 'Top executive remuneration: A view from Europe'. Fournal of Management Studies, 42, 1493-506.

Bruton, G. D., Peng, M. W., Ahlstrom, D., Stan, C. and Xu, K. (2015). 'State-owned enterprises around the world as hybrid organizations'. Academy of Management Perspectives, 29, 92-114.

*Buck, T., Liu, X. and Skovoroda, R. (2008). 'Top executive pay and firm performance in China'. Fournal of International Business Studies, 39, 833-50.

*Carney, M., Shapiro, D. and Tang, Y. (2009). 'Business group performance in China: Ownership and temporal considerations'. Management and Organization Review, 5, 167-93.

Carney, M., Gedajlovic, E. R., Heugens, P. R., Van Essen, M. and Van Oosterhout, J. (2011). 'Business group affiliation, performance, context, and strategy: A meta-analysis'. Academy of Management foumal, 54, 437-60.

*Chang, E. C. and Wong, S. M. (2004). 'Political control and performance in China's listed firms'. Fournal of Comparative Economics, 32, 617-36.

Chen, G., Firth, M., Gao, D. N. and Rui, O. M. (2006). 'Ownership structure, corporate governance, and fraud: Evidence from China'. Journal of Corporate Finance, 12, 424- 48.

*Chen, J. (2001). 'Ownership structure as corporate governance mechanism: Evidence from Chinese listed companies'. Economics of Planning, 34, 53-72.

*Chen, J., Liu, X. and Weian, L. (2010). 'The effect of insider control and global benchmarks on Chinese executive compensation'. Corporate Governance: An International Review, 18, 107-23.

Chen, J., Ezzamel, M. and Cai, Z. (2011a). 'Managerial power theory, tournament theory, and executive pay in China'. Journal of Corporate Finance, 17, 1176-99.

*Chen, J., Cumming, D., Hou, W. and Lee, E. (2013). 'Executive integrity, audit opinion, and fraud in Chinese listed firms'. Emerging Markets Review, 15, 72-91.

*Chen, J., Cumming, D., Hou, W. and Lee, E. (2014). 'CEO accountability for corporate fraud: Evidence from split share structure reform in China'. Fournal of Business Ethics, 138, 787-806.

*Chen, J., Cumming, D., Hou, W. and Lee, E. (2016). 'Does the external monitoring effect of financial analysts deter corporate fraud in China?' Journal of Business Ethics, 134, 727-42.

*Chen, V. Z., Li, J. and Shapiro, D. M. (2011b). 'Are OECD-prescribed 'good corporate governance practices' really good in an emerging economy? Asia Pacific fournal of Management, 28, 115-38.

*Chen, X., Kim, J. B., Wang, S. S. and Xu, X. (2007). 'Firm performance and the ownership of the largest shareholder'. Corporate Ownership and Control, 4, 126-38.

*Cheung, Y., Jiang, P., Limpaphayom, P. and Lu, T. (2008). 'Does corporate governance matter in China?' China Economic Review, 19, 460-79.

*Cheung, Y., Jiang, P., Limpaphayom, P. and Lu, T. (2010). 'Corporate governance in China: A step forward'. European Financial Management, 16, 94-123.

*Cho, S. and Rui, O. M. (2009). 'Exploring the effects of China's two-tier board system and ownership structure on firm performance and earnings informativeness'. Asia-Pacific Fournal of Accounting Eீ Economics, 16, 95-117.

*Choi, S. B., Lee, S. H. and Williams, C. (2011). 'Ownership and firm innovation in a transition economy: Evidence from China'. Research Policy, 40, 441-52.

Chua, R., Morris, M. W. and Ingram, P. (2009). 'Guanxi vs. networking: Distinctive configurations of affect- and cognition-based trust in the networks of Chinese vs. American managers'. Fournal of International Business Studies, 40, 480-508.

Claessens, S. and Fan, J. P. H. (2002). 'Corporate governance in Asia: A survey'. International Review of Finance, 3, 71-103.

Clarke, D. C. (2003). 'Corporate governance in China: An overview'. China Economic Review, 14, 494-507.

Cohen, J. (1960). 'A coefficient of agreement for nominal scales'. Educational and Psychological Measurement, 20, $37-46$.

Combs, J. G., Ketchen, D. J. J., Crook, T. R. and Roth, P. L. (2011). 'Assessing cumulative evidence within "macro" research: Why meta-analysis should be preferred over vote counting'. Fournal of Management Studies, 48, 178-97.

*Conyon, M. J. and He, L. (2008). CEO turnover, firm performance and corporate governance reforms in China (CRI 2009-012). Working Paper. Cornell University, ILR School, Compensation Research Initiative site: http://digitalcommons.ilr.cornell.edu/cri/12. 
*Conyon, M. J. and He, L. (2011). 'Executive compensation and corporate governance in China'. Fournal of Corporate Finance, 17, 1158-75.

Cook, R. (1979). 'Influential observations in linear regression'. Fournal of the American Statistical Association, 74, 169-74.

Cuervo-Cazurra, A. and Dau, L. (2009). 'Promarket reforms and firm profitability in developing countries'. Academy of Management fournal, 52, 1348-68.

*Cumming, D., Leung, T. Y. and Rui, O. (2015). 'Gender diversity and securities fraud'. Academy of Management fournal, 58, 1572-93.

Dalton, D. R., Daily, G. M., Ellstrand, A. E. and Johnson, J. L. (1998). 'Meta-analytic reviews of board composition, leadership structure, and performance'. Strategic Management fournal, 19, 269-90.

Dalton, D. R. and Dalton, C. M. (2011). 'Integration of micro and macro studies in governance research: CEO duality, board composition, and financial performance'. Fournal of Management, 37, 404-11.

Dalton, D. R., Hitt, M. A., Certo, S. T. and Dalton, C. M. (2007). 'The fundamental agency problem and its mitigation: Independence, equity and the market for corporate control'. Academy of Management Annals, 1, 1-64.

Davis, G. F. (2005). 'New directions in corporate governance'. Annual Review of Sociology, 31, $143-62$.

*Delios, A. and Wu, Z. J. (2005). 'Legal person ownership, diversification strategy and firm profitability in China'. Fournal of Management and Governance, 9, 151-69.

Deloitte. (2010). A Long Path to Corporate Governance: 2010 China Listed Companies Corporate Governance Survey. Deloitte, New York. Available at: https://www.deloitte.com.mx/documents/boletinfactorchina/cn_cg_2010chinalistedcocgsurvey_220410.pdf (accessed 11 August 2013).

Dewenter, K. L. and Malatesta, P. H. (2001). 'State-owned and privately owned firms: An empirical analysis of profitability, leverage, and labor intensity'. American Economic Review, 91, 320-34.

*Dong, J. and Gou, Y. (2010). 'Corporate governance structure, managerial discretion, and the R\&D investment in China'. International Review of Economics and Finance, 19, 180-8.

Doucouliagos, H. and Ulubasoğlu, M. A. (2008). 'Democracy and economic growth: A meta-analysis'. American Fournal of Political Science, 52, 61-83.

Duval, S. and Tweedie, R. (2000). 'Trim and fill: A simple funnel-plot-based method of testing and adjusting for publication bias in meta-analysis'. Biometrics, 56, 455-63.

Eden, D. (2002). 'Replication, meta-analysis, scientific progress, and AMJ's publication policy'. Academy of Management Fournal, 45, 841-6.

Erkens, D. H., Hung, M. and Matos, P. (2012). 'Corporate governance in the 2007-2008 financial crisis: Evidence from financial institutions worldwide'. Fournal of Corporate Finance, 18, 389-411.

*Fan, D. K. K., Lau, C.-M. and Young, M. (2007). 'Is China's corporate governance beginning to come of age? The case of CEO turnover'. Pacific-Basin Finance fournal, 15, 105-20.

Fan, J. H., Wong, T. J. and Zhang, T. (2007). 'Politically connected CEOs, corporate governance, and post-IPO performance of China's newly partially privatized firms'. Fournal of Financial Economics, 84, 330-57.

Filatotchev, I. and Allcock, D. (2010). 'Corporate governance and executive remuneration: A contingency framework'. Academy of Management Perspectives, 24, 20-33.

Firth, M., Fung, P. Y. and Rui, O. M. (2006). 'Corporate performance and CEO compensation in China'. Fournal of Corporate Finance, 12, 693-714.

Firth, M., Fung, P. Y. and Rui, O. M. (2007a). 'How ownership and corporate governance influence chief executive pay in China's listed firms'. Fournal of Business Research, 60, 776-85.

*Firth, M., Fung, P. Y. and Rui, O. M. (2007b). 'Ownership, two-tier board structure, and the informativeness of earnings - Evidence from China'. Fournal of Accounting and Public Policy, 26, 463-96.

*Firth, M., Fung, P. Y. and Rui, O. M. (2007c). Top Management Pay in China. Working Paper. Available at: https://pdfs.semanticscholar.org/79b2/880430192e94be01e85587881855ba945f15.pdf (accessed 28 December 2017).

Firth, M., Leung, T. Y. and Rui, O. M. (2010). 'Justifying top management pay in transitional economy'. Fournal of Empirical Finance, 17, 852-66.

Firth, M., Wong, S. M. L. and Yang, Y. (2014). 'The double-edged sword of CEO/chairperson duality in corporatized state-owned firms: Evidence from top management turnover in China'. Fournal of Management and Governance, 18, 207-44.

*Gao, L. and Kling, G. (2012). 'The impact of corporate governance and external audit on compliance to mandatory disclosure requirements in China'. Fournal of International Accounting, Auditing and Taxation, 21, 17-31. 
Geyskens, I., Krishnan, R., Steenkamp, J.-B. E. M. and Cunha, P. V. (2009). 'A review and evaluation of meta-analysis practices in management research'. Fournal of Management, 35, 393-419.

Ghosh, M. and Whalley, J. (2008). 'State owned enterprises, shirking and trade liberalization'. Economic Modelling, 25, 1206-15.

Globerman, S., Peng, M. W. and Shapiro, D. (2011). 'Corporate governance and Asian Companies'. Asia Pacific Journal of Management, 28, 1-14.

Gomez-Mejia, L., Wiseman, R. M. and Dykes, J. B. (2005). 'Agency problems in diverse contexts: A global perspective'. Fournal of Management Studies, 42, 1507-17.

Greene, W. H. (2008). Econometric Analysis. Upper Saddle River, NJ: Pearson Prentice Hall.

Groves, T., Hong, Y., McMillan, J. and Naughton, B. (1994). 'Autonomy and incentives in Chinese state enterprises'. Quarterly fournal of Economics, 109, 183-209.

*Gul, F. A., Kim, J.-B. and Qiu, A. A. (2010). 'Ownership concentration, foreign shareholding, audit quality, and stock price synchronicity: Evidence from China'. Fournal of Financial Economics, 95, 425-42.

*Gunasekarage, A., Hess, K. and Hu, A. (2007). 'The influence of the degree of state ownership and the ownership concentration on the performance of listed Chinese companies'. Research in International Business and Finance, 21, 379-95.

Guo, L., Smallman, C. and Radford, J. (2013). 'A critique of corporate governance in China'. International Fournal of Law and Management, 55, 257-72.

Harrison, J. S., Banks, G. C., Pollack, J. M., O'Boyle, E. H. and Short, J. C. (2017). 'Publication bias in strategic management research'. Fournal of Management, 43, 400-25.

Haxhi, I. and Aguilera, R. V. (2017). 'An institutional configurational approach to cross-national diversity in corporate governance'. Fournal of Management Studies, 54, 261-303.

Hedges, L. V. and Olkin, I. (1985). Statistical Methods for Meta-Analysis. Orlando, FL: Academic Press.

Hedges, L. V. and Vevea, J. L. (2005). 'Selection method approaches'. In Rothstein, H. R., Sutton, A. J. and Borenstein, M. (Eds), Publication Bias in Meta-Analysis: Prevention, Assessment, and Adjustments. Chichester: Wiley, 145-74.

Heugens, P. R., Van Essen, M. and Van Oosterhout, J. (2009). 'Meta-analyzing ownership concentration and firm performance in Asia: Towards a more fine-grained understanding'. Asia Pacific Fournal of Management, 26, 481-512.

Hoskisson, R. E., Wright, M., Filatotchev, I. and Peng, M. W. (2013). 'Emerging multinationals from mid-range economies: The influence of institutions and factor markets'. Fournal of Management Studies, 50, 1295-321.

*Hovey, M. (2004). Corporate Governance in China: An Empirical Study of Listed Firms. Doctoral Dissertation, Griffith University, Nathan, Australia.

*Hovey, M., Li, L. and Naughton, T. (2003). 'The relationship between valuation and ownership of listed firms in China'. Corporate Governance: An International Review, 11, 112-22.

*Hu, H. W., Tam, O. K. and Tan, M. G. (2010). 'Internal governance mechanisms and firm performance in China'. Asia Pacific Fournal of Management, 27, 727-49.

Hu, Y. and Zhou, X. (2008). 'The performance effect of managerial ownership: Evidence from China'. Journal of Banking and Finance, 32, 2099-110.

*Huang, G. and Song, F. M. (2006). 'The determinants of capital structure: Evidence from China'. China Economic Review, 17, 14-36.

Huang, Z., Li, L., Ma, G. and Xu, L. C. (2017). 'Hayek, local information, and commanding heights: Decentralizing state-owned enterprises in China'. American Economic Reviere, 107, 2455-78.

Hunter, J. E. and Schmidt, F. L. (2004). Methods of Meta-Analysis: Correcting Error and Bias in Research Findings, 2nd edition. Thousand Oaks, CA: Sage.

*Jian, M. and Wong, T. J. (2010). 'Propping through related party transactions'. Review of Accounting Studies, 15, 70-105.

Jiang, F. and Kim, K. A. (2015). 'Corporate governance in China: A modern perspective'. Fournal of Corporate Finance, 32, 190-216.

*Jiang, P. (2004). 'The relationship between ownership structure and firm performance: An empirical analysis over Heilongjiang listed companies'. Nature and Science, 2, 87-90.

Jiang, W., Wan, H. and Zhao, S. (2016). 'Reputation concerns of independent directors: Evidence from individual director voting'. Review of Financial Studies, 29, 655-96.

Kang, Y., Shi, L. and Brown, E. D. (2008). Chinese Corporate Governance History and Institutional Framework. Santa Monica, CA: Rand Corporation.

Kato, T. K. and Long, C. X. (2006). 'Executive compensation, firm performance, and corporate governance in China: Evidence from firms listed in the Shanghai and Shenzhen Stock Exchanges'. Economic Development and Cultural Change, 54, 945-83. 
Khanna, T. and Palepu, K. (2000). 'The future of business groups in emerging markets: Long-run evidence from Chile'. Academy of Management fournal, 43, 268-85.

Kim, H., Kim, H. and Hoskisson, R. (2010). 'Does market-oriented institutional change in an emerging economy make business-group affiliated multinationals? An institution-based view'. Fournal of International Business Studies, 41, 1141-60.

*Kling, G. and Weitzel, U. (2011). 'The internationalization of Chinese companies: Firm characteristics, industry effects and corporate governance'. Research in International Business and Finance, 25, $357-72$.

Krause, R., Semadeni, M. and Cannella, A. A. (2013). 'CEO duality: A review and research agenda'. Fournal of Management, 20, 1-31.

*Lau, C.-M., Fan, D. K. K., Young, M. N. and Wu, S. (2007). 'Corporate governance effectiveness during institutional transition'. International Business Review, 16, 425-48.

Lawrence, T. B., Winn, M. I. and Jennings, P. D. (2001). 'The temporal dynamics of institutionalization'. Academy of Management Review, 26, 624- 44.

*Le, T. V. and O’Brien, J. P. (2010). 'Can two wrongs make a right? State ownership and debt in a transition economy'. Fournal of Management Studies, 47, 1297-316.

*Li, D., Moshirian, F., Nguyen, P. and Tan, L.-W. (2007). 'Managerial ownership and firm performance: Evidence from China's privatizations'. Research in International Business and Finance, 21, 396-413.

Li, J. and Tang, Y. (2010). 'CEO hubris and firm risk taking in China: The moderating role of managerial discretion'. Academy of Management foumal, 53, 45-68.

*Li, J., Lam, K. and Moy, J. W. (2005). 'Ownership reform among state firms in China and its implications'. Management Decision, 43, 568-88.

*Li, K., Yue, H. and Zhao, L. (2009). 'Ownership, institutions, and capital structure: Evidence from China'. Fournal of Comparative Economics, 37, 471-90.

*Li, M. and Wong, Y.-Y. (2003). 'Diversification and economic performance: An empirical assessment of Chinese firms'. Asia Pacific Fournal of Management, 20, 243-65.

Li, P. P., Sekiguchi, T. and Zhou, K. (2016). 'The emerging research on indigenous management in Asia'. Asia Pacific Journal of Management, 33, 583-94.

*Li, T., Sun, L. and Zou, L. (2009). 'State ownership and corporate performance: A quantile regression analysis of Chinese listed companies'. China Economic Review, 20, 703-16.

*Li, W., He, A., Lan, H. and Yiu, D. (2012). 'Political connections and corporate diversification in emerging economies: Evidence from China'. Asia Pacific Fournal of Management, 29, 799-818.

Liang, H., Renneboog, L. and Sun, S. L. (2016). 'A state-stewardship view on executive compensation'. In Choi, J. J., Powers, M. R. and Zhang, X. T. (Eds), The Political Economy of Chinese Finance (International Finance Review, 17, 39-91). Bingley: Emerald Group Publishing Limited.

*Liang, N. and Li, J. (1999). 'Board structure and firm performance: New evidence from China's private firms'. Academy of Management Annual Conference, Chicago, IL, 7-10 August.

*Lin, C., Lin, P., Song, F. M. and Li, C. (2011). 'Managerial incentives, CEO characteristics and corporate innovation in China's private sector'. Fournal of Comparative Economics, 39, 176-90.

*Lin, C.-M., Bor-Yi, H. and Huang, C.-M. (2009). 'Corporate Owenership, Risk Characteristic and Capital Structure in Chinese Stock Companies'. Working Paper.

*Lin, P. T., Hutchinson, M. R. and Percy, M. (2009). The Role of the Audit Committee and Institutional Investors in Constraining Earnings Management: Evidence from Chinese Firms Listed in Hong Kong. Working Paper. Available at: https://eprints.qut.edu.au/37996/ (accessed 28 December 2017).

*Lin, Z. J. and Liu, M. (2009). 'The impact of corporate governance on auditor choice: Evidence from China'. Journal of International Accounting, Auditing and Taxation, 18, 44-59.

Lipsey, M. W. and Wilson, D. B. (2001). Practical Meta-Analysis. Thousand Oaks, CA: Sage.

*Liu, C., Uchida, K. and Yang, Y. (2012). 'Corporate governance and firm value during the global financial crisis: Evidence from China'. International Review of Financial Analysis, 21, 70-80.

Liu, Q. and Lu, Z. J. (2007). 'Corporate governance and earnings management in the Chinese listed companies: A tunneling perspective'. Journal of Corporate Finance, 13, 881-906.

*Liu, T. (1999). The Determinants of Corporate Capital Structure: Evidence from Listed Companies in China. Doctoral Dissertation, Concordia University, Montréal, QC.

Lu, Y., Yao, J. and Lan, H. (2004). Diversification, Internal Transactions, and Performance in Chinese Firms. Working Paper.

*Lu, Y. and Yao, J. (2007). 'Impact of state ownership and control mechanisms on the performance of group affiliated companies in China'. Asia Pacific fournal of Management, 23, 485-503. 
Luen, K., Lau, A. and Young, A. (2013). 'Why China shall not completely transit from a relation based to a rule based governance regime: A Chinese perspective'. Corporate Governance: An International Review, 21, 577-85.

*Luo, J.-H., Wan, D.-F. and Cai, D. (2012). 'The private benefits of control in Chinese listed firms: Do cash flow rights always reduce controlling shareholders' tunneling?' Asia Pacific Fournal of Management, 29, 499-518.

Ma, J. and Khanna, T. (2016). 'Independent directors' dissent on boards: Evidence from listed companies in China'. Strategic Management fournal, 37, 1547-57.

*Ma, S., Naughton, T. and Tian, G. (2010). 'Ownership and ownership concentration: Which is important in determining the performance of China's listed firms?'. Accounting \& Finance, 50, 871-97.

*Ma, X., Yao, X. and Xi, Y. (2007). 'Business group affiliation and firm performance in a transition economy: A focus on ownership voids'. Asia Pacific Fournal of Management, 23, 467-83.

Markoczy, L., Sun, S. L., Peng, M. W., Shi, W. and Ren, B. (2013). 'Social network contingency, symbolic management, and boundary stretching'. Strategic Management fournal, 34, 1367-87.

Megginson, W. L. and Netter, J. M. (2001). 'From state to market: A survey of empirical studies on privatization'. Fournal of Economic Literature, 39, 321-89.

Meyer, K. E. and Peng, M. W. (2016). 'Theoretical foundations of emerging economy business research'. Fournal of International Business Studies, 47, 3-22.

Misangyi, V. F. and Acharya, A. G. (2014). 'Substitutes or complements? A configurational examination of corporate governance mechanisms'. Academy of Management Fournal, 57, 1681-705.

*Mishra, A. V. and Ratti, R. A. (2011). 'Governance, monitoring and foreign investment in Chinese companies'. Emerging Markets Review, 12, 171-88.

Mosakowski, E. and Earley, P. C. (2000). 'A selective review of time assumptions in strategy research'. Academy of Management Review, 25, 796-812.

Mutlu, C., Wu, Z., Peng, M. W. and Lin, Z. J. (2015). 'Competing in (and out of) transition economies'. Asia Pacific Fournal of Management, 32, 571-96.

Newman, K. (2000). 'Organizational transformation during institutional upheaval'. Academy of Management Review, 25, 602-19.

*Ng, A., Yuce, A. and Chen, E. (2009). 'Determinants of state equity ownership, and its effect on value/ performance: China's privatized firms'. Pacific-Basin Finance fournal, 17, 413-43.

North, D. (1990). Institutions, Institutional Change, and Economic Performance. New York: Norton.

OECD. (2011). Corporate Governance of Listed Companies in China: Self-Assessment by the China Securities Regulatory Commission. Paris: OECD Publishing.

*Pan, X., Tian, G. G. and Cao, J. (2009). State Owened vs. Privately Owened Firms: Whose CEOs Are Better Compensated?. Working Paper. Available at: https://papers.ssrn.com/sol3/papers.cfm?abstract_ id $=1460295$ (accessed 28 December 2017).

*Pangarkar, N. and Yuan, L. (2009). 'Location in internationalization strategy: Determinants and consequences'. Multinational Business Review, 17, 37-68.

Park, S. H. and Luo, Y. (2001). 'Guanxi and organizational dynamics: Organizational networking in Chinese firms'. Strategic Management Fournal, 22, 455-77.

Peng, M. W. (2003). 'Institutional transitions and strategic choices'. Academy of Management Review, 28, 275-96.

*Peng, M. W. (2004). 'Outside directors and firm performance during institutional transitions'. Strategic Management fournal, 25, 453-71.

Peng, M. W., Bruton, G., Stan, C. and Huang, Y. (2016). 'Theories of the (state-owned) firm'. Asia Pacific Fournal of Management, 33, 293-317.

Peng, M. W. and Heath, P. S. (1996). 'The growth of the firm in planned economies in transition: Institutions, organizations, and strategic choice'. Academy of Management Review, 21, 492-528.

Peng, M. W. and Jiang, Y. (2010). 'Institutions behind family ownership and control in large firms'. Fournal of Management Studies, 47, 253-73.

Peng, M. W. and Lebedev, S. (2017). 'Intra-national business (IB)'. Asia Pacific Fournal of Management, 34, $241-5$.

*Peng, M. W., Li, Y., Xie, E. and Su, Z. (2010). 'CEO duality, organizational slack, and firm performance in China'. Asia Pacific Fournal of Management, 27, 611-24.

*Peng, M. W. and Luo, Y. (2000). 'Managerial ties and firm performance in a transition economy: The nature of a micro-macro link'. Academy of Management Fournal, 43, 486-501.

Peng, M. W., Sun, S. L. and Markoczy, L. (2015). 'Human capital and CEO compensation during institutional transitions'. Fournal of Management Studies, 52, 117-47. 
*Peng, M. W., Zhang, S. and Li, X. (2007). 'CEO duality and firm performance during China's institutional transitions'. Management and Organization Review, 3, 205-25.

*Qi, D., Wu, W. and Zhang, H. (2000). 'Shareholding structure and corporate performance of partially privatized firms: Evidence from listed Chinese companies'. Pacific-Basin Finance Fournal, 8, $587-610$.

Ralston, D. A., Terpstra-Tong, J., Terpstra, R. H., Wang, X. and Egri, C. (2006). 'Today's state-owned enterprises of China: Are they dying dinosaurs or dynamic dynamos?' Strategic Management Fournal, 27, 824-43.

Raudenbush, S. W. and Bryk, A. S. (2002). Hierarchical Linear Models: Applications and Data Analysis Methods, 2nd edition. Thousand Oaks, CA: Sage.

Rosenthal, R. (1979). 'The "file drawer problem" and the tolerance for null results'. Psychological Bulletin, 86, $638-41$.

Sauerwald, S., van Oosterhout, J., Van Essen, M. and Peng, M. W. (2018). 'Proxy advisors and shareholder dissent: A cross-country comparative study'. Fournal of Management, doi: https://doi.org/ 10.1177/0149206316675928.

Schulze, R. (2004). Meta-Analysis: A Comparison Approach. Cambridge, MA: Hogrefe \& Huber.

*Shan, Y. G. (2013). 'Can internal governance mechanisms prevent asset appropriation? Examination of type I tunneling in China'. Corporate Governance: An International Review, 21, 225-41.

*Shan, Y. G. and McIver, R. P. (2011). 'Corporate governance mechanisms and financial performance in China: Panel data evidence on listed non-financial companies'. Asia Pacific Business Review, 17, 301-24.

Sheng, H. and Zhao, N. (2012). China's State-Owned Enterprises: Nature, Performance and Reform. Singapore: World Scientific.

Shi, W., Sun, J. and Prescott, J. E. (2012). 'A temporal perspective of merger and acquisition and strategic alliance initiatives: Review and future research directions'. Fournal of Management, 38, 164-209.

Shleifer, A. and Vishny, R. W. (1997). 'A survey of corporate governance'. Fournal of Finance, 52, 737-83.

*Sun, P., Hu, H. W. and Hillman, A. J. (2016). 'The dark side of board political capital: Enabling blockholder rent appropriation'. Academy of Management fournal, 59, 1801-22.

*Sun, Q., Tong, W. H. S. and Tong, J. (2002). 'How does government ownership affect firm performance? Evidence from China's privatization experience'. Fournal of Business Finance E Accounting, 29, 1-27.

Sundaramurthy, C. and Lewis, M. (2003). 'Control and collaboration: Paradoxes of governance'. Academy of Management Review, 28, 397-415.

Tenev, S. and Zhang, C. (2002). Corporate Governance and Enterprise Reform in China: Building the Institution of Modern Market. Washington, DC: World Bank and International Finance Corporation.

*Tian, J. J. and Lau, C.-M. (2001). 'Board composition, leadership structure and performance in Chinese shareholding companies'. Asia Pacific Journal of Management, 18, 245-63.

*Tian, L. (2001). Government Shareholding and the Value of China's Modern Firms. Working Paper. Available at: https://papers.ssrn.com/sol3/papers.cfm?abstract_id=299936 (accessed 28 December 2017).

*Tian, L. and Estrin, S. (2008). 'Retained state shareholding in Chinese PLCs: Does government ownership always reduce corporate value?'. Journal of Comparative Economics, 36, 74-89.

*Tong, Y. (2002). Ownership Structure, Corporate Performance and Insider's Control: An Empirical Study on Listed Chinese Companies. Working Paper.

Tosi, H., Werner, S., Katz, J. and Gomez-Mejia, L. (2000). 'How much does performance matter? A meta-analysis of CEO pay studies'. Fournal of Management, 26, 301-39.

Tsui, A. (2007). 'From homogenization to pluralism: International management research in the Academy and beyond'. Academy of Management fournal, 50, 1353-64.

Van Essen, M., Heugens, P. R., Otten, J. and Van Oosterhout, J. (2012a). 'An institution-based view of executive compensation: A multilevel meta-analytic test'. Fournal of International Business Studies, 43, 396-423.

Van Essen, M., Van Oosterhout, J. and Carney, M. (2012b). 'Corporate boards and the performance of Asian firms: A meta-analysis'. Asia Pacific Journal of Management, 29, 873-905.

Van Essen, M., Otten, J. and Carberry, E. J. (2015). 'Assessing managerial power theory: A meta-analytic approach to understanding the determinants of CEO compensation'. Fournal of Management, 41, 164-202.

Wagner, J. A., Stimpert, J. L. and Fubara, E. I. (1998). 'Composition and board organizational performance: Two studies of insider/outsider effects'. Journal of Management Studies, 35, 655-77.

*Wang, J., Guthrie, D. and Xiao, Z. (2011). 'The rise of SASAC: Asset management, ownership concentration, and firm performance in China's capital markets'. Management and Organization Review, 8 , 253-81. 
*Wang, L. and Judge, W. (2012). 'Managerial ownership and the role of privatization in transition economies: The case of China'. Asia Pacific Journal of Management, 29, 479-98.

*Wang, P. (2008). Subtle Decoupling Policy from Practice: The Case of Ownership Restructuring Plans in Chinese Fraud Firms. Working Paper.

*Wei, L.-Q., Lau, C.-M., Young, M. N. and Wang, Z. (2005). 'The impact of top management team demography on firm performance in China'. Asian Business \& Management, 4, 227-50.

*Wei, Z., Xie, F. and Zhang, S. (2005). 'Ownership structure and firm value in China's privatized firms: 1991-2001'. Fournal of Financial and Quantitative Analysis, 40, 87-108.

Westphal, J. D. and Graebner, M. (2010). 'A matter of appearances: How corporate leaders manage the impressions of financial analysts about the conduct of their boards'. Academy of Management Fournal, 53, $15-44$.

*Xia, D. and Zhu, S. (2009). 'Corporate governance and accounting conservatism in China'. China Fournal of Accounting Research, 2, 81-108.

*Xiao, H. and Yuan, J. (2007). 'Ownership structure, board composition and corporate voluntary disclosure'. Managerial Auditing Fournal, 22, 604-19.

Yang, J., Chi, J. and Young, M. (2011). 'A review of corporate governance in China'. Asian-Pacific Economic Literature, 25, 15-28.

*Yiu, D., Bruton, G. D. and Lu, Y. (2005). 'Understanding business group performance in an emerging economy: Acquiring resources and capabilities in order to prosper'. Fournal of Management Studies, 42, 183-206.

*Yiu, D. W., Hoskisson, R. E., Bruton, G. D. and Lu, Y. (2014). 'Dueling institutional logics and the effect of strategic entrepreneurship in Chinese business groups'. Strategic Entrepreneurship Fournal, 8, 195-213.

Young, M., Peng, M. W., Ahlstrom, D., Bruton, G. D. and Jiang, Y. (2008). 'Corporate governance in emerging economies: A review of the principal-principal perspective'. Fournal of Management Studies, 45, 196-220.

*Yu, W. (2009). Management Compensation and CEO Turnover in Chinese Business Groups. Working Paper. Available at: https://papers.ssrn.com/sol3/papers.cfm?abstract_id=1440531 (accessed 28 December 2017).

*Yuan, R., Xiao, J. Z. and Zou, H. (2007). 'Mutual funds' ownership and firm performance: Evidence from China'. Fournal of Banking \& Finance, 32, 1552-65.

*Zhan, W. and Turner, J. D. (2012). 'Crossing the river by touching stones?: The reform of corporate ownership in China'. Asia-Pacific Financial Markets, 19, 233-58.

*Zhou, N. (2008). Institutional Environment and Diversification Strategy of Chinese Listed Firms: An Investigation of H-Share Firms. Working Paper.

*Zhu, J. (2007). 'The empirical study on the effect factor of top management remuneration in China'. Fournal of American Academy of Business, 11, 213-9. 